\title{
Releváns-e a humor a relevanciaelméletben?
}

\author{
Nemesi Attila László \\ PPKE Magyar Nyelvészeti Tanszék
}

\begin{abstract}
Összefoglaló
A dolgozatban azt vizsgálom, hogy a relevanciaelmélet milyen értelmezését tudja adni a tisztán nyelvi és a nyelvi összetevőt is tartalmazó multimodális humorjelenségeknek. Mivel kognitív pragmatikai elmélet, amelyet nem a humor magyarázatára dolgoztak ki, hanem a kommunikációnak mint a valóság megismerésére irányuló információfeldolgozásnak az általános modelljeként, tisztázásra szorul, hogy fogalmi apparátusa és alaptézisei mennyiben alkalmasak a humor természetének megragadására. Dinamikus kontextusfelfogása és a következtetési múveletek középpontba állítása kifejezetten elönyös a humoros diskurzusok mélyreható magyarázatában. Kérdéses viszont, hogy mindent átfogó kommunikációs alapelve hogyan vonatkoztatható a humoros szándékú megnyilatkozásokra, amelyek jellemzően kijátsszák a relevanciakeresés heurisztikáját, miközben a humoros hatás szempontjából mégiscsak relevánsak. Ha a humorral nem is, a vele sürün összefonódó iróniával a relevanciaelmélet a kezdetektől foglalkozik, ezért ezt a fejezetét kritikus elemzésnek vetem alá. A nyelvi példákat többféle müfajból, illetőleg szövegtípusból merítem.
\end{abstract}

Kulcsszavak: humor, relevancia, relevanciaelmélet, explikatúra, implikatúra, kontextus, irónia

\section{Bevezetés}

A Sperber és Wilson (1995 [1986]) által kidolgozott relevanciaelmélet a kortárs pragmatikakutatás egyik vezető, Magyarországon is jól ismert és művelt irányzata (magyar nyelven I. pl. a Helikon című folyóirat 2006/4. számát, valamint: ReboulMoeschler (2000 [1998]); Németh T. (2003; 2006); Nemesi (2009); Bárány-Zvolenszky-Tőzsér (2015)). Kommunikációfogalma azokat az eseteket öleli fel, amikor valaki (vagy valakik) valamilyen információt szeretne (vagy szeretnének) valaki (vagy valakik) tudomására hozni úgy, hogy ebbéli szándékát (vagy szándékukat) nyilvánvalóvá is teszi(k). Nincs az elmélet a nyelvi kommunikációra korlátozva, de indulásától kezdve elsősorban a nyelvi megnyilatkozások értelmezési folyamataira összpontosít, kulcsszerepet tulajdonítva az elme mint megismerő rendszer relevanciamaximalizálásra való beállítódásának (minél nagyobb mentális „haszon” minél kisebb mentális „költség” árán). Szeretné áthidalni azt az űrt, amely a nyelvileg kódolt (konvencionális, szemantikai) jelentés és a szándékolt, illetőleg kikövetkeztetett (kommunikációs, pragmatikai) jelentés között mutatkozik. Erre utal az „aluldetermináltsági tézis" (Carston 2002: 15-30). A megnyilatkozásjelentés nyelvi aluldetermináltsága Grice (1975) óta a pragmatika egyik központi témája. 
Noha a humoros szövegek bőséges példatárai az aluldetermináltsági tézisnek, nem vonták magukra Sperber és Wilson figyelmét. Követőik között azonban többen is akadtak/akadnak, akik megpróbálták/megpróbálják kiterjeszteni az elméletet ilyen irányba is (ezeknek a törekvéseknek a szintézise Yus (2016), kivonata Yus (2017)). Tanulmányomban részletesen megvizsgálom a humor relevanciaelméletbe való beillesztésének gondolatát, mint tettem azt korábban a grice-i-leechi társalgásimaxima-elmélet (Nemesi 2016 [2011]: 135-159; 2015a) és a beszédaktuselmélet (Nemesi 2016) vonatkozásában, egy rövid összevetésig is eljutva (Nemesi $2015 b$ ), amelyben már esett szó a relevanciaelméletben rejlő lehetőségekről és korlátokról. Itt alaposabban körbejárom a kérdést, többféle müfajt és szövegtípust bevonva a vizsgálatba. Magának a humor fogalmának a meghatározási nehézségeiről és viszonylagosságáról sokan írtak (I. pl. Attardo 1994; Martin 2007; Schnurr 2010; Nemesi 2018). A relevanciaelmélet nyelvéhez igazodva elöljáróban azt mondhatjuk, hogy adva van egy stimulus (nyelvi, nem nyelvi vagy multimodális közlés), amely mulattat egy befogadót (hatás), akár volt ilyen szándéka a közlőnek, akár nem. Ha volt, akkor ebből a szempontból (is) relevánsnak szánta a stimulust, vagyis a hatás (mulattatás) kedvéért (is) hozta létre, amely hatás rendszerint jól látható-hallható - mosoly, nevetés stb. -, de e külső megnyilvánulásai többé-kevésbé kontrollálhatók, elfojthatók, azaz nem szükségszerüek, bár nagyon jellemzőek. Nézzük tehát, mit tud mondani a relevanciaelmélet a humoros nyelvi (vagy nyelvi összetevőt is tartalmazó multimodális) stimulusokról.

\section{A kontextus(ok) felépítése}

Szembetűnő hiányossága a klasszikus pragmatikaelméleteknek, hogy nincs bennük kimunkálva a kontextus fogalma és közremüködése a beszélői szándékok kifejezésében, illetőleg a nyelvi megértésben. A megnyilatkozások elemzésénél adottnak veszik a hozzájuk tartozó (többnyire magával a megnyilatkozással együtt kitalált) kontextust, amely közös és egyformán elérhető a résztvevők számára. Austin (1990 [1962]: 87, 107, 139, 150-151) és Searle (2009 [1969]: 30-31, 42, 84), bár több helyütt utalnak arra, hogy a beszédaktusok értékét („erejét”) és elfogadhatóságát befolyásolja a megnyilatkozás kontextusa (pl. „Az ő szájából utasításnak vettem, s nem kérésnek"; a „»szeretném, ha nem tennéd meg“ [...] bizonyos kontextusokban jóval több lesz, mint pusztán egy óhaj kifejezése"), és az illokúciós aktusok sikerfeltételei tartalmaznak a kontextusra vonatkozó előírásokat, végül is mellőzik a fogalom definiálását. Grice-nál (1975: 50; 2011 [1989]: 35) ugyanezt figyelhetjük meg: az implikatúra levezetéséhez szükséges adatok között felsorolja a megnyilatkozás „nyelvi vagy egyéb kontextusát” és „a háttértudás további elemeit”, de hogy ezek pontosan mit is foglalnak magukba, azt nem fejti ki, csupán példáinak rövid glosszáiból tudunk valamelyest következtetni rájuk.

A grice-i modell kritikájából (Wilson-Sperber 1981) kinőtt relevanciaelmélet egyik újdonsága és erénye, hogy a kontextusépítést árnyaltan tudja modellezni. Ez témánk szempontjából azért különösen fontos, mert a humor tipikus velejárója, hogy a szereplők (és/vagy a hallgató, a néző) először más kontextust építenek föl magukban, mint amit „kellene”. Ha a kontextust nem eleve meglévőnek tételezzük fel, hanem megnyilatkozásról megnyilatkozásra alakulónak, jobban meg tudjuk magyarázni a félreértéseket (vö. Yus 1999; Ivaskó-Németh T. 2002; Ivaskó 2005) 
és a következtetések humoros tévösvényeit (vö. Yamaguchi 1988; Jodłowiec 1991; Dynel 2009). ${ }^{1}$

Vegyünk egy példát a kontextusok humoros célzatú manipulálására (Verschueren 1999: 110-111; Tátrai 2004: 491; 2011: 66; 2017: 949): A tacskó című közkedvelt bohózatban a Rátonyi Róbert által alakított apa félreértelmez egy levelet, amelyet Vera nevü lányának (Pap Vera) küldtek Veszprémből. Vera korábban ott dolgozott, és hozzájutott egy kiskutyához, de mindaddig titokban akarta tartani szülei előtt, amíg be nem költöznek az új lakásukba. A közönség erről már a bohózat elején értesül, amikor Vera elmeséli a tervezett meglepetést barátnőjének, Erzsikének, aki szintén szeretett volna egy kutyát ajándékozni nekik. Vera apját a levél kihozza a sodrából. Felolvastatja feleségével:

$$
\begin{aligned}
& \text { „Kedves kisasszony! Örömmel értesítem, hogy a kicsi szépen fejlődik. Már } \\
& \text { a legtöbbször kikéredzkedik. Most már csak ritkán fordul elő, hogy a szobá- } \\
& \text { ban megy ki... Azt hiszem, most már nyugodtan hazaviheti a kisasszony. } \\
& \text { Nagyon aranyos kis tacskó.” }
\end{aligned}
$$

A szülők azt a téves kontextust építik föl az (1)-hez, hogy lányuk, mialatt Veszprémben volt, gyermeket szült, és a levelet az írta, akinél „a kicsit” eddig rejtegette. Ennek fényében döbbenten hallgatják Vera válaszait, aki nem érti a felháborodást:

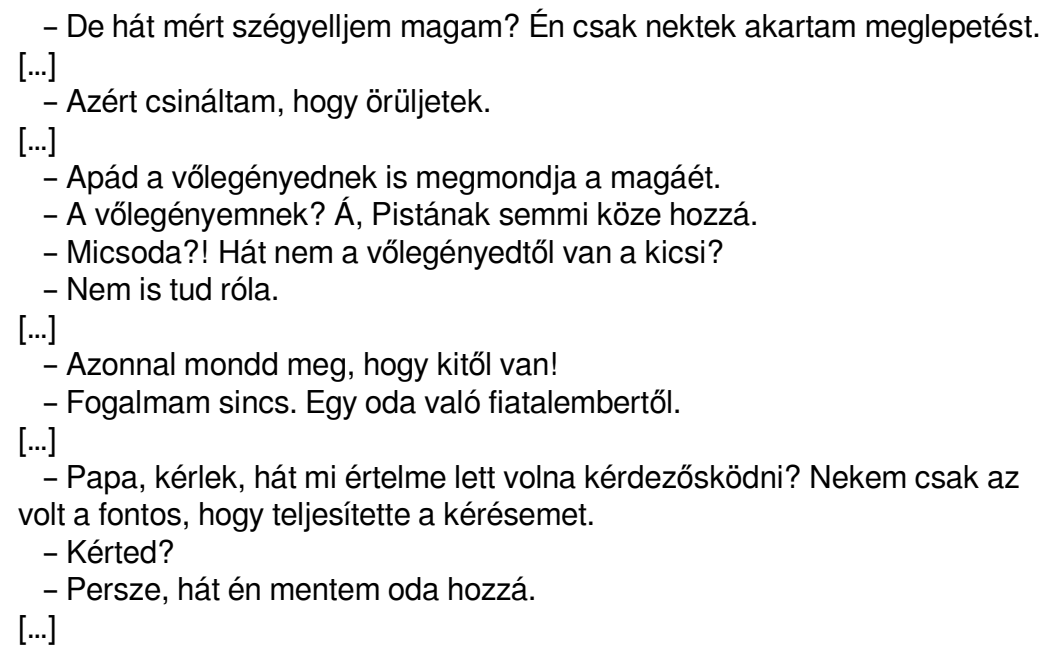

\footnotetext{
${ }^{1}$ Más pragmatikaelméletek is a dinamikus és komplex kontextusfelfogás mellett érvelnek (Verschueren 1999: 75-114; Tátrai 2004; 2011: 51-67; 2017: 927-952). A legismertebb nyelvészeti humorelmélet a szemantikai forgatókönyv fogalmába integrálja a fikción (a vicc világán) belüli kontextuális tényezőket, két forgatókönyv váratlan ütközésével magyarázva a humoros csattanót (Raskin 1985). Továbbfejlesztett változata hat „tudásforrás”-ról beszél: forgatókönyv-ütközés, logikai mechanizmus, szituáció, célpont, narratív stratégia és nyelv (AttardoRaskin 1991; magyarul I. Nemesi 2015b: 124-132; 2018: 47-52).
} 
- Anyu, hát mért kell ebből ekkora ügyet csinálni? Ha nem akarjátok, akkor otthagyom Veszprémben.

- Hogyhogy otthagyod?

- Hát úgy, hogy megírom annak az asszonynak, akinél van, hogy adja oda valakinek...

A félreértés tehát nem tudatosul a bohózat karaktereiben (a szülök szerint lányuk „nem normális”, „megbolondult”). Sőt, tovább fokozódik, amikor betoppan egy idegen férfi, mit sem sejtve arról, hogy Veráék új lakásában pár napja már nem egy falvédőket és plakátokat forgalmazó vállalat irodája müködik. Ennél a vállalatnál szeretné ugyanis értékesíteni apró gyermekeket ábrázoló falvédőit. Vera apja a veszprémi fiatalembernek nézi:

- Na végre valaki... Jó napot kívánok!

- Jó napot!

- Kérem szépen, én vidékről jöttem... a... nem tudom, hogy kivel kell tárgyalnom a... gyermek miatt.

- A gyermek miatt?

- Igen, kérem. Biztos tetszett már hallani róla.

- Persze... Milyen minőségben van érdekelve a dologban?

- Há' hogyhogy minőségben, kérem szépen, hát... a gyermek az én müvem, kérem.

- A maga müve?!

- Igen, kérem, a legsikerültebb alkotásom.

- Nekem ne hencegjen vele!

- Nem, nem hencegés, kérem. Ahány asszony meglátja, az... az mind könyörög, hogy ő is akar egy ugyanolyat.

[...]

- ... pedig nem is csinálom olcsón.

- Hát maga pénzt kér érte?!

- Mért, talán ingyen adjam? Hát én ebből élek, kérem.

- Szép kis foglalkozás... S maga ezt ilyen nyíltan bevallja?

- Há' mért tagadnám? Engedélyem van rá a tanácstól.

[...]

- Én ahhoz ragaszkodom, hogy a lányomat elvegye feleségül!

- Az nagyon nehéz lesz, tudniillik én nős ember vagyok, kérem...

- Nős???

- Igen, nős vagyok...

- S ilyesmiket csinál?

- Na de hogy jön ez ide, kérem? Hát attól én még igazán nős lehetek.

- És ahhoz mit szólna, hogyha a felesége megtudná, hogy maga ilyesmivel foglalkozik?

- Hogyha megtudná? Hát tudja! Én otthon a lakásban csinálok mindent.

Nem szükséges talán ennél bővebben, Vera magából kikelt apjának nem verbális reakcióit is érzékeltetve idézni a jelenetet ahhoz, hogy lássuk: a két szereplő a másik minden soron következő megnyilatkozását a saját kontextusába próbálja beilleszteni, azt építve tovább, és csak a bohózat végére derül ki, miért okozott ez 
mindkét félnek nehézséget. ${ }^{2}$ Mivel fikciós müfajról van szó, nem érdemes azt firtatnunk, mennyire valószerü, hogy ilyen sokáig elhúzódik a kölcsönös félreértés. Koncentráljunk inkább arra, mely összetevőkből vezetné le a relevanciaelmélet az apa kontextusát.

Az egyik forrás: milyen fogalmakat kódolnak azok a szavak, amelyek a megnyilatkozásokban előfordulnak, és milyen nagyobb enciklopédikus információhalmazt aktiválnak a hallgató fejében. A főnévi KIcsı fogalom az (1)-ben első hallásra/olvasásra kisgyermeket, csecsemőt kódol, ami zavartalanul beilleszthető a levél állításaiba, mert a hozzá tartozó enciklopédikus tudásnak része, hogy a kisgyermekek két-három éves korukig nem szobatiszták. A TACSKó fogalma késztethetné az addig felépített kontextus elvetésére a szülőket, hiszen a tacskó mindenekelőtt egy 'rövid lábú, hosszú testü, lecsüngő fülű kutyafajta'. Másodlagosan azonban lehet pejoratív ('éretlen, felelőtlen kölyök') vagy akár kedveskedő ('csintalan, de kedves kisgyerek') metaforikus szinonimája is a KIcSI-nek. Ez utóbbi értelmezés kerekedik felül különösebb kétely nélkül, így a (2)-(3)-nak már az lesz az előzetes kontextusa az apa és a (2)-ben az anya számára is, hogy lányuknak titokban gyermeke született, és az, aki Veszprémben neveli, elérkezettnek látja az időt arra, hogy Vera hazavigye, mivel már majdnem szobatiszta. Ha mindenáron ehhez akarjuk igazítani Vera megnyilatkozásait a (2)-ben, tényleg úgy tűnhet föl, hogy a lány „megbolondult”: nemhogy nem szégyelli magát, amiért házasság előtt és szülei tudta nélkül gyermeket szült, de még örömet is akart ezzel szerezni nekik, ráadásul nem a vőlegény a „kicsi” apja, hanem egy olyan férfi, akit egyszerűen megkért erre annak ellenére, hogy nem ismeri. Mi több, a gyermeket otthagyná és „elajándékoztatná” Veszprémben, hogy elképedt szüleit megnyugtassa...

A valóságnak Vera előzetes kontextusa felel meg, ám mivel föl sem vetődik benne, hogy szüleinek a kontextuális feltevései a „kicsi” szó félreértése miatt különböznek az övéitöl, azt hiszi, a kutya ellen van indokolatlanul heves kifogásuk. A (3)ban a falvédőkészítő kisiparos rögtön a GYERMEK fogalmat állítja középpontba, amelyet Vera apja a KIcsı-vel azonosít, és a levél alapján kreált, majd a (2)-ben kiegészített kontextusba helyezi mindazt, amit hall. Így lesz megbotránkoztató, hogy a „gyermek” a nem különösebben jó megjelenésű férfi „műve”, „legsikerültebb alkotása”, hogy pénzt kér érte, mert ebből él, hogy nős stb. - aki viszont joggal furcsállja, hogy lebecsülik a foglalkozását, házasságra akarják kényszeríteni, és kifogásolják, hogy nős. Ha nála lenne a falvédő, és megmutatná, vagy például a levélhez egy fénykép lenne mellékelve a tacskóról, Vera apja közvetlen érzékszervi úton jutna olyan információhoz, amely érvénytelenítené a téves feltevésekből kiinduló kontextust. Három forrása van tehát a kontextust alkotó feltevéseknek: a diskurzuselőzmény (a megnyilatkozás nyelvi kontextusa, szövegkörnyezete), a megnevezett fogalmak által elérhetővé váló enciklopédikus ismerethalmaz

\footnotetext{
${ }^{2}$ Hasonló példa Goatly (2012: 248-249) monográfiájából: egy gyermektelen házaspár tíz év után elhatározza, hogy spermadonorhoz fordul. A férj dolgozni megy, a feleség otthon várja az ismeretlen férfit. Véletlenül épp egy utazó bébifotós jár a környéken, és amikor becsönget, elkezdődik a két vágányon futó - nekünk, olvasóknak szándékoltan kétértelmű - párbeszéd. A fotós ugyanis olyan (angol) kifejezéseket használ, amelyeket ő a fényképezés, az asszony viszont a nemi aktus mikéntjére vonatkoztat (pl. „If we try several different positions and I shoot from six or seven angles, I'm sure you'll be pleased with the results").
} 
(világtudásdarabok) és a közvetlen fizikai környezetből nyerhető információ (szituációs kontextus). Ez együtt - amit a relevanciaelmélet az egyén kognitív környezetének (cognitive environment) nevez - elvben rendkívül sok feltevést hívhatna elö, köztük számos irrelevánsat. A kontextus valójában a kognitív környezet leszükített halmaza. Meg kell tehát mondania a relevanciaelméletnek, mi alapján szűkítik a társalgók a kognitív környezetet a kontextusra, vagyis mi kerül végül bele.

\section{Megértés és megismerés}

Mint minden megismerő lényé a maga komplexitási fokán és létfenntartási feltételei között, az ember elméje is úgy müködik, hogy a lehető legpontosabb reprezentációt próbálja megalkotni a világról. Automatikusan arra fókuszál, mi lehet ebből a szempontból releváns információ az éppen aktuális kognitív környezetben. A kontextus feltevések kiválasztásával jön létre: a hallgató, amikor találkozik egy megnyilatkozással, a kommunikatív relevancia elve alapján interpretálja azt, és ehhez keresi azokat a feltevéseket, amelyekből levezethető a legnagyobb kognitív hatással és a legkisebb kognitív erőfeszítéssel járó értelmezés. Minél kisebb hatást eredményez, illetőleg minél nagyobb műveleti energiát igényel egy feltevés előhívása, annál kevésbé releváns. A kommunikatív relevancia elve az osztenzív-következtetéses kommunikáció eseteire érvényes (Sperber-Wilson 1995 [1986]: 63, 158, 260-261; Wilson-Sperber 2004: 610-614; Reboul-Moeschler 2000 [1998]: 90-97; Carston 2002: 378-379):

a) Osztenzív-következtetéses kommunikáció:

A kommunikátor létrehoz egy stimulust, ami kölcsönösen nyilvánvalóvá teszi a résztvevő felek előtt a kommunikátor abbéli szándékát, hogy a stimulussal nyilvánvalóvá vagy még nyilvánvalóbbá akar tenni a hallgató(ság) számára egy $\{$ I\} feltevéshalmazt.

b) A kommunikatív relevancia elve:

Az osztenzív-következtetéses kommunikáció minden megnyilvánulása saját optimális relevanciájának elvárását közvetíti.

Az optimális relevancia vélelmezése azt jelenti, hogy ha az osztenzív-következtetéses kommunikáció esete forog fenn, a hallgató nyugodtan feltételezheti, hogy a beszélő a tőle telhető legrelevánsabb stimulust produkálta az $\{\mid\}$ feltevéshalmaz közlése érdekében, és az ebböl származó pozitív (a kognitív funkciók és célok megvalósulásához hozzájáruló) kognitív hatás ellensúlyozni fogja a megértéshez szükséges kognitív erőfeszítést (Sperber-Wilson 1995 [1986]: 266-271). A hallgató tehát keresi a kognitív környezetében elérhető azon feltevéseket, amelyek hozzásegítik a legrelevánsabb interpretációhoz, és ezek a feltevések alkotják a kontextust. Van azonban itt némi körben forgás: ha a kontextust alkotó feltevések kiválasztását a relevancia keresése irányítja (i. m. 141), bármilyen feltevés relevanciáját viszont csakis valamilyen kontextusban lehet megállapítani (i. m. 125), akkor a kontextust alkotó feltevéseknek is kell, hogy legyen saját kontextusuk (benne az éppen interpretálandó megnyilatkozással). Vagyis fennáll annak a veszélye, hogy a kontextus meghatározása végtelen regresszióba torkollik, mert a relevancia és a kontextus fogalmát nem sikerül egymástól függetlenül definiálni (vö. Leezenberg 2001 [1995]: 
113; Franken 1999: 147; Nemesi 2009: 92). A másik alapvető probléma, hogy a kognitív hatás és erőfeszítés nem mérhető, így a relevanciaelméleti apparátus túl általános ahhoz, hogy megbízható empirikus előrejelzéseket adjon a feltevések súlyozásáról (Levinson 1989; 2000: 57-59).

Amennyiben a humor belefér az osztenzív-következtetéses kommunikáció fogalmába, a kommunikatív relevancia elve ugyanúgy érvényes lesz rá, mint a nem humoros osztenzív (a kommunikátor informatív szándékát nyilvánvalóvá tevő) stimulusokra. A relevanciaelmélet iskolateremtő teoretikusai (Dan Sperber, Deirdre Wilson, Diane Blakemore ${ }^{3}$ és Robyn Carston $^{4}$ ) - e tekintetben Austin, Searle és Grice nyomdokain haladva - nem térnek ki részletesen a humor kérdésére. Mások viszont magától értetődő természetességgel kísérlik meg alkalmazni a poszt-grice-i téziseket a viccekre és további humorjelenségekre (Jodłowiec 1991; Curcó 1995; 1996; Yus 2003; 2008; 2016; 2017; Biegajło 2013). Kézenfekvő (lenne) a humort is (kognitív) hatásként felfogni, amely valamilyen nehézségi fokú gondolkodási erőfeszítést (következtetéseket) igényel.

\section{A humoros megnyilatkozások relevanciája}

Azt már láttuk, hogyan épülhet ki a humoros kontextus. Vegyük most szemügyre magát a humoros megnyilatkozást. Egy megnyilatkozás nyelvi formája (a relevanciaelméletben: logikai forma) gyakran hiányos - a kontextus alapján a hallgató egészíti ki, hogy teljes értékű állítás (vagy kérdés stb.) legyen. Előfordulhat ugyanis, hogy elmaradnak bizonyos mondatrészek, amelyeket a szintaktikai szabályok ugyan megkövetelnek, de mivel könnyű őket azonosítani a kontextus alapján, pragmatikai okból mégis elhagyhatók. ${ }^{5} \mathrm{Az}$ is előfordul, hogy egy kifejezés referenciája a kontextusból töltődik fel, mert vagy deiktikus névmás, határozószó, vagy többértelmű

\footnotetext{
${ }^{3}$ Blakemore (1992: 13-14) csupán annyit mond, hogy egyes viccek a következtetések törlését használják ki, idézve is egy ilyet: Izgatott hölgy gyorsan hívná az orvost, mert a fia „lenyelte a töltőtollat”, az azonban a sok várakozó páciensére hivatkozva csak három-négy óra múlva ígéri, hogy megy. „Három vagy négy óra... Mit fogok addig csinálni?” - kérdezi döbbenten az asszony, mire az orvos azt javasolja neki, hogy írjon ceruzával. Bár a poén a kérdés mögötti szándék félreértésén, azaz félrekövetkeztetésen alapul (mit fog közben csinálni a fiával - mivel fog írni), az orvos első reakciójából mindjárt arra következtethetünk, hogy orvos létére nem következtette ki az abszurd balesettel járó életveszélyt és a beavatkozás sürgősségét. A következtetések tehát még egy ilyen rövid viccnél is többlépcsősek és többszintüek lehetnek (a viccszereplök következtetései - a viccmesélö és a hallgató következtetései). A fikciós kommunikáció szintjeiről és azok elkülönítésének fontosságáról I. Yamaguchi (1988); Brock (2011); Dynel (2011); Nemesi (2015a).

${ }^{4}$ Carston (2002: 137) megemlíti, hogy humoros hatás származhat egy-egy implikált premisszából, például:
}

- Ki az az úriember, akivel tegnap este láttalak?

- Nem úriember volt, hanem szenátor.

Az implikált premissza: 'A szenátorok nem úriemberek'. Másutt (i. m. 302) a visszhangszerü megnyilatkozások lehetséges humorára találunk futólagos utalást.

${ }^{5}$ Ezek általában az ige kötelező vonzatai (argumentumai). Maga az ige is elhagyható, mint például a (2)-ben: „A vőlegényemnek?” ('A papa megmondja a magáét a vőlegényemnek?'), vagy a (3)-ban: „A gyermek miatt?" ('A gyermek miatt jött tárgyalni?'). 
(nyelvileg kódoltan vagy kontextuálisan). A nyelvileg kódolt jelentés tehát nem mindig elégséges ahhoz, hogy egy megnyilatkozás propozíciós tartalmát explicitté tegyük: szükség van pragmatikai müveletekre is. Gondoljunk a kicsi, a tacskó és a gyermek referenciájának hozzárendelésére a fönti bohózatban, vagy az olyan névmások értelmezésére, mint az ebból a (2)-ben („Anyu, hát mért kell ebből ekkora ügyet csinálni?” - miből?), vagy a rá a (3)-ban („Engedélyem van rá a tanácstól” mire?). Az így teljessé vált propozíciót a relevanciaelmélet - a grice-i implikatúra analógiájára - explikatúrának nevezi. Bár megértésük következtetéseket is igényelhet, az explikatúrákat expliciten kommunikáljuk (így a grice-i „mondott” jelentésbe tartoznak), míg az implikatúrákat impliciten - vallják az irányzat képviselői (SperberWilson 1995 [1986]: 176-183; Blakemore 1992: 57-63; Carston 2002: 116-164, 377). ${ }^{6}$ A megnyilatkozás implikatúráját (vagy implikatúráit) az explikatúrából és a kontextust alkotó feltevésekből tudja levezetni a hallgató (vö. Wilson-Sperber 2004: 615). Mindez azt jelenti, hogy explikatúra nincs kontextus nélkül, kontextus nincs logikai forma nélkül, implikatúra pedig nincs explikatúra és kontextus nélkül. A kommunikatív relevancia elve csak a logikai formát nem befolyásolja - a kontextus kiválasztását, az explikatúra meghatározását és az implikatúra levezetését igen.

Amire a relevanciaelméletet kidolgozták, legkevésbé sem az, hogy megmondja, mitöl lesz humoros egy szöveg. Mivel radikálisan redukcionista, nincsenek olyan interakciós posztulátumai (mint a beszédaktus-elméletben a sikerfeltételek vagy a grice-i együttmüködési alapelv és maximái), amelyek nem teljesülése a humor lehetőségét hordozná. Amit viszont mindenképpen meg kell magyaráznia, az az, hogyan érti meg a hallgató a szöveg humorát. Az általános recept úgy szól, hogy a hallgató automatikusan a kommunikatív relevancia elvével összhangban lévő interpretációt részesíti előnyben, amit a beszélő előre meg tud tervezni, miközben úgy alakítja a szöveget, hogy ez utóbb érvénytelennek bizonyuljon egy eredetileg kevésbé releváns interpretációval szemben (Jodłowiec 1991; Curcó 1995; Yus 2003; 2017). Ennek a szerkesztési stratégiának számos változata létezik. Az egyik az explikatúrák láncolatának $A$ tacskó című bohózatban is megfigyelhető humoros inkongruenciája. Rövidebb szövegekben, például egy viccben elég egyetlen rosszul interpretált explikatúra is a poénhoz:

(LVk. 230.)

Beteg a súlyemelő felesége. Az orvos megvizsgálja az asszonyt, majd felír egy gyógyszert.

- Ezt váltsa ki - mondja a bajnoknak -, és minden órában egy evőkanállal adjon belőle a feleségének, de előbb mindig rázza fel...

Alig ér haza az orvos, a súlyemelő máris telefonál.

- Doktor úr! A feleségem elvesztette az eszméletét.

- Lehetetlen. És mikor?

- Amikor először kezdtem rázni.

A humoros félreértés abból adódik, hogy a felráz ige tárgyi argumentuma - amit az orvos a gyógyszernek, a súlyemelő viszont a feleségének feleltet meg - a párbeszéd

\footnotetext{
${ }^{6}$ A teljesen explicit és a teljesen implicit jelentések közötti „szürke zónát” más kutatók másféleképpen osztják fel (I. pl. Bach 1994; Levinson 2000: 194-198; Carston 2002: 94-221; Recanati 2004).
} 
első megnyilatkozásában implicit marad. ${ }^{7}$ A vicc végén derül ki, hogy a súlyemelő rossz explikatúrát kreált. Az orvos kanalas gyógyszert ír fel, és ha „felrázást” említ, enciklopédikus ismereteink alapján az a legnagyobb kognitív hatással és a legkisebb mentális erőfeszítéssel járó, vagyis a legrelevánsabb feltételezés, hogy a gyógyszert kell felrázni. Igaz, hogy alvó vagy csüggedt embereket is „fel lehet rázni”, de a beteg feleségnek sem szó szerint, sem metaforikusan nem ilyen bánásmódra van szüksége. A súlyemelő azok közé a vicckarakterek közé tartozik, akiknek tökéletlen a pragmatikai kompetenciája. Utolsó két megnyilatkozásából a viccbeli orvos és a vicc hallgatója is ki tudja következtetni, hogy akkora erővel (a súlyemelőkhöz kapcsolódó enciklopédikus tudás) „rázta fel” a feleségét, hogy az ennek következtében elvesztette az eszméletét. Ezt azonban nem a súlyemelő karakter implikálja, hanem a vicc szövege, illetőleg a viccmesélő.

Egy másik lehetőség Wilson és Sperber (1992; 2012: 123-145) iróniafelfogásából következik (Goatly 2012: 265-273; Curcó 1995; 1996). Az irónia igen gyakran humoros, és humora a relevanciaelmélet szerint abban az implicit disszociatív attitüdben (attitűdimplikatúrában) rejlik, amely a beszélő elhatárolódását juttatja kifejezésre egy másvalakinek tulajdonított és kölcsönösen nyilvánvalóvá tett („visszhangoztatott”) feltevéstől:

(6) Ne mondd folyton egy nőnek, hogy nem vagy méltó hozzá. Legyen neki teljes meglepetés.

Curcó (1996) terminológiájával: adva van egy kölcsönösen nyilvánvaló explicit kulcsfeltevés (a partner nem méltó a hölgyhöz) és egy implicit célfeltevés (a partner méltó a hölgyhöz) a (6) kontextusában, amelyek inkongruensek. Az első megnyilatkozás után a célfeltevés tűnik föl relevánsabbnak a tekintetben, mit gondolhat a beszélő, ám a második megnyilatkozásból - amely teljes propozíciós formára kiegészítve: „Legyen neki teljes meglepetés, hogy nem vagy méltó hozzá” - kikövetkeztethető explikatúra és attitűdimplikatúra végül a kulcsfeltevést erősíti meg, amely udvariatlan ${ }^{8}$ a partnerre nézve, de a nők számára sem éppen hízelgő.

A relevanciaelmélet iróniaértelmezésének egyik gyengéje a visszhangoztatott használat (echoic use) fogalmának felpuhítása, a másik pedig az irónia felismerésének felületes tárgyalása. Eleinte a visszhangoztatás valaki vagy valakik egy korábbi megnyilatkozásának vagy vélt gondolatának megismétlését - ahogy Sperber és Wilson (1981) mondja: említését (mention) - jelentette egy bizonyos attitüddel, amely ironikus visszhangoztatás esetén az iróniára jellemző elhatárolódás (kétségbe vonás, helytelenítés, kritizálás, gúny, megvetés, nevetségessé tétel). Bár egy azelőtt el sem hangzó, csupán valaki(k)nek tulajdonított gondolat vagy elképzelt megnyilatkozás „visszhangoztatása” önmagában is vitatható fogalomtágítás, így sem bizonyult kielégítőnek a magyarázat. Az említést az értelmező hasonlóság (interpretive resemblance) koncepciója váltotta fel, amely megengedi, hogy az eredeti megnyilatkozást vagy gondolatot egy annak reprezentálása alkalmas (ahhoz hasonló, azt értelmező) másikkal visszhangoztassa a beszélő (Wilson-Sperber 1992). Ezzel a

\footnotetext{
${ }^{7} \mathrm{Az}$ implicit igei argumentumok azonosításáról I. Németh T. (2006: 244-256) és Németh T. (2013a: 187-188).

${ }^{8} \mathrm{Az}$ udvariatlanság nagyban hozzájárul a példa humorához: a beszélő először mintha követné a leechi (1983) jóváhagyás- és rokonszenvmaximákat, majd váratlanul megsérti őket.
} 
visszhangoztatás teljesen összecsúszik a klasszikus retorikából jól ismert allúzió fogalmával (vö. Kumon-Nakamura-Glucksberg-Brown 1995; Komlósi 2007: 122).

A (6)-hoz elegendő lenne az elmélet első, említéses változata is, amennyiben a beszélő a megszólított partnert szó szerint idézi. Ha nem, mert nem pontosan azt szokta mondogatni a nőknek, hogy „Nem vagyok méltó önhöz/magához/hozzád”, hanem csak valami tartalmilag hasonlót (pl. „Úgy érzem, ön fölöttem áll”, „Nálam jobbat érdemelsz"), akkor mutatkozna meg a visszhangoztatás értelmező hasonlóságra való kiterjesztésének jelentősége. De bármilyen lazán értelmezzük is a visszhangoztatást, vajon minden esetben fölleljük az iróniában? A (7)-beli anekdota azt bizonyítja, hogy nem:

\section{(LVk. 61.)}

Jászai Mari vidéken vendégszerepelt. A partnere csapnivalóan gyenge színész volt. Jászai a próbán küszködött vele, tanította, magyarázott neki eredménytelenül. Este, az előadáson sikerült is elrontania Jászai legszebb jelenetét.

- Mondja, kérem - fakadt ki a művésznő -, miért lett maga színész?

- Mert ellenállhatatlan vágyat éreztem a világot jelentő deszkák iránt.

Mire Jászai komor királynői fenséggel válaszolt:

- Akkor miért nem lett asztalos?...

A humoros csattanó nyilvánvalóan ironikus: megvan benne az irónia sine qua nonja, a negatív, disszociatív attitűdimplikatúra. Ugyanakkor nem visszhangoztat semmit, hanem a színpad perifrázisában („a világot jelentő deszkák”) metonimikus értelmű deszka szónak a konkrét, szó szerinti jelentését állítja az irónia szolgálatába a föltett nem valódi (költői, tettetett; vö. Clark-Gerrig 1984) kérdésben - a deszka szó fogalmilag elérhetővé teszi az asztalost (enciklopédikus ismeret, azonos fogalmi tartomány vagy jelentésmező). Az igaz, hogy Jászai ironikus attitüdje a tehetségtelen kolléga előző, némiképp közhelyes megnyilatkozására vonatkozik, és az abban kifejezett magasztos attitüddel ellentétes, de sem szó szerint, sem értelmezve nem ismétli meg azt. Visszhangoztathatta volna a híres színésznő ironikusan: „Ellenállhatatlan vágyat...”. Vagy: „A deszkák iránt...”. Ehelyett azonban hozzákapcsol egy (ál)kérdést, amely a deszka szó poliszémiájából meríti az iróniával együtt frappáns szellemességét. Figyeljük meg, hogy éppen így lesz az esetből jó anekdota. A puszta visszhangoztatás nem tenné azzá, mert nem lenne különösebben humoros.

Kellér Dezső (1957: 152) Nyelvvédelem címü „egyperces konferansza” szintén ironikus megnyilatkozással végződik. Erre sem alkalmazható Sperber és Wilson iróniaelmélete:

(8) Talán, mert mostanában annyi szó esik róla, valamelyik este a feleségem leemelte a könyvespolcról Balassa József $A$ magyar nyelv könyve címü múvét. Megfogtam a kezét.

- Ne kezdj bele!

- Miért? - nézett rám csodálkozva.

- Azért, szívecském, mert ezt a könyvet te csak akkor olvasnád el, ha benne a névelő a végén elvenné az időhatározót, vagy, mondjuk, ha a főnevet rejtélyes körülmények között meggyilkolnák, és aztán kiderülne, hogy az egyik igenév a tettes... 
A sugallt jelentés kettős: az egyik implikátum az, hogy Kellér feleségét kizárólag a romantikus regények és a krimik kötik le, ezért Balassa müve nem lenne számára elég izgalmas olvasmány, a másik pedig a konferanszié ehhez való ironikus viszonyulása (attitüdje). A feleség valamilyen gondolatának vagy megnyilatkozásának visszhangoztatására itt nem lehet hivatkozni, ellenben a Wilson és Sperber (2012: 134-136) által bírált „irónia mint tettetés” elmélet (Grice 1978; Clark-Gerrig 1984) okfejtése hozzáigazítható a példához: azáltal ismeri fel a hallgató/olvasó az ironikus attitüdöt, hogy felismeri a komolyság tettetésének felismertetésére irányuló beszélői szándékot. A megnevezett szófajok ${ }^{9}$ regényhősként való megszemélyesítése (metafora) megfosztja komolyságától a megnyilatkozást, más beszélői attitűdöt kell tehát keresni. Innen már visszatérhetünk a relevanciaelmélet általános interpretációs mechanizmusához (a kontextus kiválasztása, az implikatúrák levezetése a kommunikatív relevancia elve alapján), mert riválisa jóval kevésbé explicit. Röviden összegezve a (6), a (7) és a (8) elemzésének tanulságát: a relevanciaelmélet iróniaelképzelése újszerü, de parciális, mert a visszhangoztatás ugyan gyakori eleme és nyomravezetője az ironikus megnyilatkozásoknak, ám nem definitív tulajdonsága (Komlósi 2007: 122; Nemesi 2009: 98-99; Garmendia 2015).

Ha nem lenne parciális, akkor is meg kellene állapítanunk, hogy vannak irónia nélküli humoros implikatúrák. Vegyük például a (9)-et:

(LVk. 63.)

Egy cannes-i filmfesztiválon - még a hatvanas években - Sophia Loren mélyen dekoltált estélyi ruhában jelent meg a fogadáson. Keblei között, nyakába akasztott aranyláncon egy miniatür arany repülőgép volt a medál.

Az este folyamán egy híres mürepülőt is bemutattak a müvésznőnek.

A pilóta megbüvölve bámulta az arany repülőgépet:

- Micsoda pompás masina! - mondta. - És milyen isteni kifutópálya!

Az „isteni kifutópálya” (metafora) a színésznő dekoltázsa: a különös medál által felidézett fogalmi tartomány kivetítése a fedetlenül hagyott, nőiesen szép testfelületre olyan képzettársítás, amelynek humoráról inkább a relevanciaelmélet metaforamagyarázatának (I. alább) kellene számot adnia, nem az iróniával foglalkozó fejezetének, hiszen nincs benne irónia. Mindjárt hozzáteszem: az általam preferált iróniafelfogás szerint nincs, amelynek lényege a sugallt negatív (kritikus) attitűd mint conditio sine qua non (Nemesi 2009; vö. Garmendia 2010; 2014; Dynel 2013; 2018). Nem zárható ki, hogy más iróniafogalom alapján a (9) utolsó megnyilatkozása ironikusnak minősül (a relevanciaelméleté alapján mindenesetre semmiképp sem az). Ráadásul nemcsak az iróniaértelmezések különbözősége teszi nehézzé a humor és az irónia szétválasztását, hanem az ironikus (kritikus) attitűdnek az ugratástól a szarkazmusig terjedő fokozatisága (Nemesi 2009: 67-69) és nézőpontfüggősége (Tátrai 2011: 190-204). Ha van egyáltalán valami - mondjuk, az indiszkrét kérdést feltevő újságírónak szóló - irónia Marilyn Monroe alábbi válaszában, az nagyon finom. A helyszín a londoni Savoy Hotel, ahol rengeteg riporter és

${ }^{9}$ Hogy egészen pontosak legyünk, az időhatározó nem szófaji, hanem mondattani kategória. A határozószó - és azon belül az időhatározó-szó - tartozik a szófajok közé (Keszler 2000: 209-222, 428-448). 
fotós gyűlt össze arra a bejelentésre, hogy az amerikai színésznő és Laurence Olivier együtt játszik majd egy filmben (The Prince and the Showgirl, 1957):

(MA. 257.)

- Mit visel, amikor ágyba megy?

Monroe a férjére, Arthur Miller drámaíróra pillant, majd így felel:

- Chanel 5-öt.

Az ismert parfümmárka említésével Monroe azt implikálja, hogy nem visel az ágyban semmilyen ruhanemüt. Szellemes, humoros és/vagy ironikus-e, illetőleg mennyire az - erről bizonyára megoszlanának a vélemények, mert mindhárom fogalom viszonylagos. Mégis megkockáztatom: inkább humoros, mint nem, és inkább nem ironikus, mint ironikus.

A (11)-gyel kapcsolatban már határozottabbak lehetünk. Benne a híres tenorista, Luciano Pavarotti bókja nem hordoz iróniát, s ha frappáns humorát nem vitatjuk, a (9)-hez hasonlóan elfogadható - egyébként szintén figuratív jelentésű - példát találtunk az implikatúrával kifejezett nem ironikus humorra (az implikatúra: 'Lindströmnek mindene tökéletes, gyönyörü nő'):

(ZA. 152.)

Luciano Pavarotti köztudottan szeretett flörtölni. Egy alkalommal Pia Lindström, Ingrid Bergman gyönyörü lánya készített vele televíziós interjút. Lindström megjegyezte, hogy egy kritikus nemrég azt sugallta a közönségnek, hogy Pavarotti hangszálain „Isten csókja” érződik. Pavarotti azonnal reagált:

- Én meg azt hiszem, Önt mindenhol megcsókolta.

A jelen tanulmány szövegforrásait tanulmányozva azonban ki lehet jelenteni, hogy a humoros implikatúrák túlnyomó része egyúttal többé-kevésbé ironikus vagy valamilyen nézőpontból annak is tekinthető.

Az explikatúrákkal és implikatúrákkal való kreatív játékok mellett Yus (2008: 153-155; 2016: 172-189) az enciklopédikus tudás, a társadalmi és kulturális sztereotípiák humoros megkérdőjelezésére is kitér. Egyik példája egy nagyon kövér humorista előadásából származó részlet:

(12) Manapság mindenki tökéletes testet szeretne. És, amint látják, nekem sikerült. Mondhatná valaki: „De hát ez a fickó kövér!” Hát igen, persze. Csakhogy nekem ez a tökéletes test. Az emberek annyira megszállottan fogyni akarnak, hogy nem veszik észre, milyen sok előnye van annak, ha valaki kövér. A vékony embereknek undorító dolgokat kell enniük, hogy megőrizzék alakjukat, míg azok az ételek, amiket nekünk, kövéreknek kell ennünk, hogy megtartsuk a miénket, mind finomak. ${ }^{10}$

\footnotetext{
${ }^{10}$ Hoy todo el mundo busca tener un cuerpo perfecto. $Y$ yo, como pueden ver, lo he conseguido. Alguno dirá: “¡Pero si está gordo!” Pues sí, claro. Es que para mi eso es un cuerpo perfecto. La gente está tan obsesionada con perder kilos que no se da cuenta de que estar gordo tiene muchas ventajas. Los delgados tienen que comer unas cosas asquerosas para mantener su figura, mientras que las cosas que tenemos que comer los gordos para mantener la nuestra están todas buenísimas. (Yus 2016: 188-189)
} 
A „tökéletes test” társadalmi-kulturális sztereotípiái - például az identitással összefüggésben - élénken foglalkoztatják a szociálpszichológusokat (I. Csabai-Erős 2000). Bármit is gondoljunk róla, azt biztosan kijelenthetjük, hogy a mai nyugati kultúrában a kövérség fogalma és látványa nem fér össze sem a férfi, sem a női testideállal. Yus szerint a közönség relevánsnak találja az ilyen sztereotípiáknak ellentmondó fejtegetéseket, ám ha nem bizonyulnak elég meggyőzőnek, akkor senki sem fogja törölni a sztereotípiát az enciklopédikus információk tárából. Márpedig a fönti érvelés aligha győzi meg a hallgatót/olvasót. Nem is ez a célja - inkább úgy tesz, mintha elfogadható lenne, és a humorista komolyan hinne abban, hogy a kövér test tekinthető tökéletesnek. De hogyan keletkezik, és végső soron mi a humor, ha a kontextuális hatás csupán egy korábban már elraktározott sztereotípia megerősödése ${ }^{11}$ Nyilvánvalóan nem ezért lesz releváns a (12) mint humoros diskurzus. Ragaszkodva ahhoz a tézishez, hogy a megértést kizárólag az elme azon igyeke$z^{2} e^{12}$ irányítja, hogy a valóságról minél pontosabb és teljesebb képet alkosson, annyit mondhatunk, hogy adva van a „tökéletes test” két, inkongruens reprezentációja, melyek közül a sztereotipikus az érvényes; a másikat csak azért kreálja a humorista, hogy a kettő kontrasztjával mulattasson. ${ }^{13}$ Csakhogy a közönségben kiváltott derű is valamifajta kontextuális hatás, ${ }^{14}$ ahogy azt az előző pont végén hajlamosak voltunk elfogadni, ha nem is feltétlenül fejezhető ki propozíciós formájú információként (feltevésként), és nem is járul hozzá önmagában a valóság leképezéséhez.

Konceptualizálhatnánk mint gyenge implikatúrát vagy gyenge implikatúrák együttese által kiváltott különleges kontextuális hatást a poétikai hatáshoz (SperberWilson 1995 [1986]: 222-224; Pilkington 1992; 2000) hasonlóan, ha előbb világos meghatározását tudnánk adni ennek az implikatúratípusnak. Sperber és Wilson (1995 [1986]: 199-211) szerint az implikatúra "gyengesége”, amely fokozati, a sugallt feltevés szándékoltságának bizonytalanságát jelenti - azaz a hallgató nem lehet egészen biztos abban, hogy a beszélő tényleg az adott feltevést implikálta, vagy valami mást (l. még Grice 1975: 58; Blakemore 1992: 128-131; Carston 2002: 381). Ugyanakkor azt is kezdettől fogva hangsúlyozzák, hogy nem csupán propozíciós formájú reprezentációk keletkeznek a megértés során (pl. képek, benyomások, érzelmek), amivel egy kognitív pragmatikaelméletnek valamit kezdenie kell (Wilson-Sperber 1981: 163; Sperber-Wilson 1981: 296-297; 1995 [1986]: $57,59)$. Ezeket összefüggésbe próbálják hozni a gyenge implikatúrákkal (SperberWilson 1995 [1986]: 222-224; I. még Nemesi 2009: 137-149). Ha elfogadnánk, hogy a fönti értelemben vett gyenge implikatúrák váltják ki a humort mint nem propozíciós hatást, meg kellene tudnunk válaszolni a kérdést, mi a különbség a

${ }^{11}$ Kontextuális hatás a relevanciaelmélet keretében abból származhat, hogy egy új információ (1) megerősít vagy (2) gyengít/érvénytelenít egy régi, ismert feltevést, illetőleg (3) új konklúziót eredményez (kontextuális implikáció).

${ }^{12}$ A kognitív relevancia elve: „Az emberi megismerés a relevancia maximalizálására törekszik" (Sperber-Wilson 1995 [1986]: 260; Carston 2002: 45, 379).

${ }^{13}$ Neo-grice-i szemmel észre kell vennünk egy sor maximasértést a (12)-ben: túlzásokat, esetleg (ön)iróniát („mindenki tökéletes testet szeretne”, a beszélőé „tökéletes”, a vékony embereknek undorító ételeket kell enniük, a kövéreké viszont mind finom), szerénytelenséget (a beszélőnek sikerült elérnie a tökéletes testet).

${ }^{14}$ A kognitív hatás nem más, mint kontextuális hatás egy kognitív rendszerben, például egy egyénben (Sperber-Wilson 1995 [1986]: 265; Carston 2002: 376). 
poétikai hatás és a humoros hatás között, hiszen mindkettő gyenge implikatúráknak lenne köszönhető. A helyzet akkor igazán zavarba ejtő, amikor például egy metaforának humoros és poétikai hatása egyaránt lehet.

Legyen ezúttal a forrásunk Petőfi komikus eposza, $A$ helység kalapácsa. A templomba bezárt kovács, a „széles tenyerű Fejenagy” - az elbeszélő szavaival élve - gondolatok seregét főzi „feje bográcsában”, hogy kitalálja, miként juthatna onnan ki (első ének), később pedig azt a néma vallomást tulajdonítja a „szemérmetes Erzsóknak”, hogy ő (mármint Fejenagy) lenne a „csapra ütője” az asszony „Szíve hordójának” (harmadik ének). Két sajátságos „tartályt” ismernének itt fel a kognitív metaforaelmélet képviselöi (pl. Kövecses 2005 [2002]): (1) A FEJ BOGRÁcs, a gondolatok ebben megfőzhető ételalapanyagok (I. a mindennapi nyelvből a „nyers gondolatok”, „sületlen ötletek” konvencionális metaforikus kifejezéseket); (2) A Szív BOROSHORDÓ, melynek tartalma, a bor minden gyöngéd érzés, szerelem, amit egy asszony érezhet egy férfi iránt (I. a mindennapi nyelvből: „kiönti a szívét”, „Szabad folyást enged az érzelmeinek”). Kövecses (2005 [2002]: 59-68; I. még Lakoff-Turner 1989) a költői nyelvhasználatban a hétköznapi metaforák továbbfejlesztését látja - jelen esetben alkalmasint A GONDOLATOK ÉTELEK és AZ ÉRZELEM TARTÁLYBAN LÉVŐ FOLYADÉK fogalmi metaforák egyedi kidolgozására mutatna rá. Ez a metaforikus továbbfejlesztés, egyedi kidolgozás lehet a záloga a poétikai hatásnak, de önmagában nem feltétlenül záloga a humornak. A humorhoz az kell, hogy a kidolgozás ne csak egyedi, de a társas-társadalmi valóság görbe tükre is legyen. Az olvasó észleli, hogy a problémamegoldó gondolkodás és a szerelem hőskölteményekre jellemző emelkedettsége áll szemben a bográcsban főzés és evés, illetőleg a borkimérés (Erzsók asszony kocsmáros) és borivás (van arra utalás a szövegben, hogy ő is szereti a bort) képi-fogalmi profanitásával. Petőfi e kiemelt metaforái - immár a relevanciaelmélet nyelvén, amely elveti a konnotáció fogalmát, és (a kognitív metaforaelmélettel ellentétben) nem hivatkozik fogalmi tartományok közötti leképezésekre sem - hozzásegítenek számos kontextuális feltevéshez; gyenge implikatúrák sorozatát vezetjük le, és ad hoc fogalmak keletkeznek, amelyek bizonyos konstellációja poétikai hatásként, más konstellációja humoros hatásként jelentkezik. Lesz egy-egy ad hoc BOGRÁCS*, FÖZ*, illetőleg BOROSHORDÓ*, CSAPRA ÜT* stb. fogalmunk, amelyek eltérnek a fejünkben rögzült (lexikalizálódott) BOGRÁCS, FÖZ, BOROSHORDÓ, CSAPRA ÜT fogalmaktól, bár természetesen nem függetlenek tőlük, belölük keletkeznek. Hogy mégis hogyan képzelendő el ezeknek az ad hoc fogalmaknak a létrejötte, mentális reprezentációja, és pontosan milyen gyenge implikatúrákat vezetünk le milyen premisszák alapján, majd ezek hogyan állnak össze poétikai vagy humoros hatássá - ezt kell(ene) részletesen és meggyőzően kifejtenie a relevanciaelméleti interpretációnak (vö. Pilkington 1992; 2000; Carston 2002: 320-375; Vega Moreno 2007; Wilson 2011; Wilson-Sperber 2012: 97-122; magyarul Sperber-Wilson 2013 [2008]; Nemesi 2012; Zvolenszky-Bárány 2015).

Van olyan vicctípus, amelyik azért humoros, mert fölösleges műveleti erőfeszítésre készteti a hallgatót, illetőleg túl gyenge kognitív hatást produkál (Goatly 2012: 253). Éppen ezért az efféléket egyesek talán hajlamosak „favicc”-nek minősíteni:

(LVk. 443.)

- Hogy hívják a kínai tüzoltót?

- Telefonon. 
A bosszantóan evidens válasz szempontjából irrelevánsnak bizonyul, hogy milyen „nemzetiségü” a tűzoltó. Így nézve szükségtelen a „kínai” fogalomhoz járuló enciklopédikus információkat aktiválni. Nem szükségtelen azonban a vicc szempontjából: a kérdés elhiteti velünk, hogy nagyon is releváns, mivel sok vicc kezdődik úgy, hogy „Hogy hívják a kínai...”, „Hogy hívják a japán...”, „Hogy hívják a görög...” telefonszerelőt, agglegényt, kártyást stb., amire a humoros felelet egy-egy kínai, japán, görög stb. hangzású (vagy azt imitáló), de értelmes magyar szóalakokból összeszerkesztett „név”, például „Nicsak Kicseng” (a kínai telefonszerelő), „Maradoka Magamura” (a japán agglegény), „Namilesz Teosztasz” (a görög kártyás). Háttérben marad ezért a hív ige másik jelentése, a 'telefonon hív', amelyet a kihív, felhív igekötős alakok egyértelművé tennének. Az az információ, hogy a tűzoltókat telefonon hívják, igen csekély kontextuális hatással bír (megerősít egy különben is erős enciklopédikus feltevést), ha beszélhetünk egyáltalán kontextuális hatásról, következésképp viccünknek kognitív relevanciája alig van, csupán „humorrelevanciája”, ami abban áll, hogy várakozásainkkal szemben nem egy kínai névre hasonlító kreatív magyar nyelvi leleményt, hanem egy banális információt kapunk.

Mivel a létrehozott stimulus lehet nyelvi, nem nyelvi és multimodális is (I. Németh T. 2011: 48-53), a relevanciaelméleti interpretáció kiterjeszthető a nem verbális és multimodális humorjelenségekre (Yus 2016: 263-319) - de csak a szándékolt humorra. A nem szándékolt humor ugyanis nem osztenzív-következtetéses kommunikáció, jóllehet akár a humoros nyelvbotlásokra, akár a szójátéknak ható véletlen nyelvi megfogalmazásokra gondolunk, ezek olyan megnyilatkozásokban fordulnak elő, amelyek egyébként osztenzív-következtetéses kommunikációnak számítanak (Gil 2011). Annyi lesz a különbség egy tisztán nyelvi és egy olyan multimodális keresztrejtvényvicc megértése között, mint a (14), hogy a kiinduló fogalmak és feltevések egy részét nem nyelvileg dekódoljuk, hanem vizuálisan:

(TS. 19.)

- Két fiú után örülnék egy lánynak, és nem lennék hálátlan!

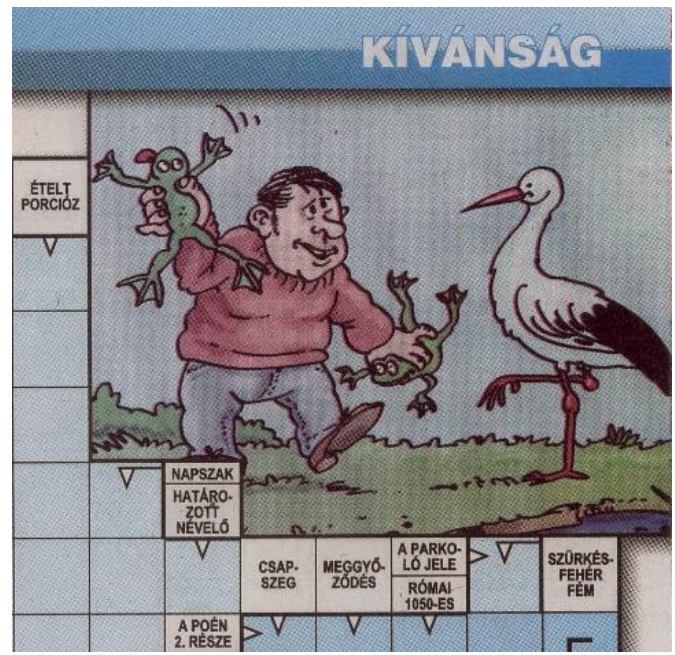


A kép és a megfejtés együtt humoros: a karikatúrán az látható, hogy egy hóbortos férfi (l. a szemeinek ábrázolását) két élő békát visz egy gólyának, a megfejtés pedig magyarázatot ad arra, miért teszi ezt (úgy gondolja, a gólya hozza a gyermekeket, és a gólya azt is befolyásolni tudja, milyen legyen a nemük). A következő feltevéseink keletkeznek:

(i) Egy hóbortos férfi két kezében két élő békát visz egy gólyának. ( $\leftarrow$ Képi információ.)

(ii) A békák félnek a gólyától. ( $\leftarrow$ Képi információ és enciklopédikus tudás.)

(iii) A gólyák egyik kedvenc tápláléka a béka. ( $\leftarrow$ A gólya és a békák látványa által előhívott enciklopédikus tudás.)

(iv) A férfinak két fia van, és örülne, ha a következő gyermeke lány lenne. ( $\leftarrow$ Nyelvi információ a megfejtésböl.)

(v) A férfi a gólya közbenjárását kéri ahhoz, hogy a következő gyermeke lány legyen. ( $\leftarrow$ Nyelvi információ a kép felirata és a megfejtés alapján.)

(vi) A gólya a néphit szerint ismeri az élet forrását, onnan hozza a gyermekeket. ( $\leftarrow$ A gólyához kapcsolódó enciklopédikus tudás.)

(vii) A férfi szó szerint igaznak tartja a (vi) néphitet. $(\leftarrow$ Következtetés a kép, a felirat és a megfejtés alapján.)

(viii) A férfi azt hiszi, hogy a gólya megérti a szándékát, illetőleg az emberi beszédet (és esetleg beszélni is tud). ( $\leftarrow$ Következtetés a kép, a felirat és a megfejtés alapján.)

(ix) A férfi „ajándékként” hozza a gólyának a békákat, hogy a kedvében járjon, és további hasonló ,jutalmat” helyez kilátásba, amennyiben a gólya teljesíti kívánságát. ( $\leftarrow$ Következtetés a kép, a felirat és a megfejtés alapján.)

(x) A férfi azt hiszi, hogy a hozott békákkal és hálája további kifejezésével el tudja érni, hogy a gólya közbenjárásával következő gyermeke lány legyen. $(\leftarrow$ Humoros következtetés az (i)-(ix) alapján.)

Eltöprenghetünk azon, vajon származik-e bármiféle pozitív kognitív hatás ebből a következtetési láncolatból. Ha semmivel sem járul hozzá az emberi megismerés céljaihoz, akkor kognitív szempontból értelmetlen és haszontalan elfoglaltság vicceket olvasni. Megerősödhet ugyan bennünk néhány enciklopédikus információ a békákról, a gólyákról és a gólyákkal kapcsolatos néphitről, valamint a rejtvényújságok multimodális humoráról, ám ezen kívül a (14) aligha pontosítja a világtudásunkat. Természetesen, ha valaki először találkozna keresztrejtvényviccel, nem ismerné a néphitet, vagy mit sem tudna a gólyák táplálkozásáról, akkor számára világos kognitív nyereség kínálkozna, amely kárpótolná a befektetett mentális erőfeszítésért. De a többieket mi kárpótolja, hogyha az elmét pusztán megismerő rendszernek tekintjük?

Az (i)-(x) reprezentációk egy fiktív világról szólnak. Jobban megvizsgálva vannak köztük értelmező metareprezentációk (egyszerű reprezentációk magasabb rendű reprezentációi) a hóbortos férfi gondolatairól („azt hiszi, hogy...”). Összetettebb metareprezentációkat is meg tudunk alkotni (pl. „A karikaturista azt gondolja, hogy az olvasó humorosnak fog találni egy olyan férfit, aki azt hiszi, hogy ha békákat ad a gólyának, azzal rá tudja venni, hogy legközelebb lánygyermeket hozzon neki”). A kifinomult megértéshez elengedhetetlen a fejlett metareprezentációs 
képesség és az episztemikus éberség (epistemic vigilance), vagyis az állandó kalkulálás azzal, hogy a közlő szándéka nem komoly, nem őszinte vagy nem jóhiszemű (Sperber 2000; Sperber et al. 2010). A humormegértést nagyban segítik a humor nyelvi és nem nyelvi jelölői (I. pl. Fónagy 1970; Attardo-Pickering-Baker 2011; vö. az irónia jelölőivel: Attardo et al. 2003; Komlósi 2014). Voltaképp minden humoros szándékú megnyilatkozás megértése együtt jár annak a metareprezentációnak a megalkotásával, hogy „A beszélő humoros akart lenni azzal, hogy azt mondta/írta: ...”. Ez kétségtelenül némi kognitív nyereség, de nem azonos a szándékolt vagy nem szándékolt humor keltette hatással: azzal, hogy valami mulattat bennünket. A humoros irónia látszólag paradox mivoltán tűnődve Yus (2016: 219236) úgy próbálja meg feloldani az irónia disszociatív és a humor jellemzően pozitív attitűdje közötti ellentmondást, hogy bevezet egy másik metareprezentációs szintet a humor érzelmi attitűdjének, amely nem egy propozícióra vonatkozik, mint az irónia disszociatív attitűdje, hanem hozzáadódik, azonosítva a humoros szándékot.

\section{Hatás és erőfeszítés mérlege}

Úgy fest, a humor a relevanciaelmélet perspektívájából a megismerésre törő emberi információfeldolgozás „mellékterméke” csupán. Akár gyenge implikatúrák nyalábja, mint a poétikai hatás, akár metareprezentáció, akár valami más a relevanciaelmélet híveinek szemében, vitathatatlanul mindennapi jelenség, amellyel sok időt töltünk, és általában a kommunikáció részének tekintjük. Ha a megnyilatkozások relevanciája a belölük származó kognitív hatástól és az ehhez szükséges kognitív erőfeszítéstől függ, a humor pedig nem kognitív hatás, miközben feldolgozása erőfeszítést ugyanúgy igényel, mint a releváns megnyilatkozásoké, akkor a relevanciaelméletnek el kell ismernie, hogy legalábbis néha nem csupán a megnyilatkozások relevanciáját keressük, hanem például az örömet, a szórakozást, a kikapcsolódást (Piskorska 2005: 252). Vagy elfogadjuk, hogy a kommunikáció nem kizárólag a megismerést szolgálja, és ennek megfelelően kitágítjuk a fogalmát úgy, hogy a humor és az esztétikum is beleférjen (pl. az informatív szándék mellett egyéb szándékokat is belefoglalunk az osztenzív-következtetéses kommunikáció definíciójába), vagy mégiscsak kognitív/kontextuális hatásként kell elkönyvelnünk a humort és a stílushatást - ehhez pedig a kogníció fogalmát kell kitágítani. Máskülönben ugyanis hiányozni fog a humor és az esztétikum motivációja a relevanciaelméletből. Billy Clark (2013: 73, 143-144), érzékelve a problémát, a rétegzés (layering; vö. Clark 1996: 353-384) fogalmát kínálja föl megoldásnak: a kommunikációnak több szintje vagy „rétege” van, és attól, hogy egy megnyilatkozás nem optimálisan releváns, még használható osztenzív stimulusként a kommunikáció egy második rétegében. Ez az elgondolás azonban bővebb kifejtést igényelne Clarktól, mert sem az nem világos, hogyan érvényesül - ha érvényesül - a kommunikatív relevancia elve a kommunikáció második rétegében (pl. milyen kognitív hatás keletkezik), sem az, miként konceptualizáljuk és hová helyezzük magát a humoros hatást, sem pedig az, hányféle rétege lehetséges a kommunikációnak, s ezek hogyan épülnek egymásra (I. még a manipulatív szándék kérdését: Árvay 2003; 2004; Németh T. 2013b; 2015). Yus (2016: 31, 54-59) kibővíti a hatás/erőfeszítés általános relevanciaelméleti formuláját a pozitív/negatív kontextuális megszorítások és a pozitív/negatív nem propozíciós hatások kalkulálásával. Kontextuális megszorítás lehet 
például, hogy alkalmas-e a helyzet a humorizálásra, rendelkezik-e a hallgató a szükséges háttérismeretekkel, milyen a humorérzéke, neme, származása, hangulata, a beszélő előadói képessége. Mindez adott esetben befolyásolja a humor relevanciáját. Pozitív nem propozíciós hatás például a társas baráti kapcsolat, a csoportidentitás erősítése, a szolidaritás növelése, de ilyen maga a nevetés, a derű, a szórakozás, amelynek következménye lehet a bizalmas viszony megteremtése stb., vagyis bármilyen érzelem, benyomás, amely a résztvevőkben keletkezik - így természetesen az is, ha valakit nem mulattat a humorizálási kísérlet, sőt visszatetszést kelt benne (l. negatív propozíciós hatás). Ezzel a javaslatával Yus a kogníció fogalmát szélesíti.

Hacsak nem faviccről vagy egyéb gyengének értékelt humorról van szó, a humoros hatás ellensúlyozni tudja a befogadó müveleti erőfeszítését. De mit is jelent pontosan a műveleti erőfeszítés? Röviden: „a figyelem, a memória és a következtetőképesség" müködtetését. ${ }^{15}$ Mint már utaltunk rá, sem a kognitív (vagy más) hatás, sem a müveleti erőfeszítés nem mérhető egzakt módon, bár egyes pszicholingvisztikai módszerekkel (olvasási idő, reakcióidő mérése, szemmozgáskövetés stb.) némi betekintést nyerhetünk a mentális tevékenységbe (I. pl. Noveck-Sperber 2004; Gibbs-Colston 2012). A pragmatikakutató nem tud hozzáférni a figyelem vagy a memória folyamataihoz, ellenben a következtetés ösvényeit fel tudja deríteni. Nem meglepő tehát, hogy a relevanciaelmélet elsősorban ezzel foglalkozik a „műveleti erőfeszítés” (processing effort) címszava alatt. Míg a kognitív/kontextuális hatás a megértés haszna, a műveleti erőfeszítés a költsége, negatív faktora (Sperber-Wilson 1995 [1986]: 124). Minél erőfeszítés-igényesebb, összetettebb a következtetési folyamat, annál kisebb a relevancia, és annál nagyobb hatás képes csak kiegyensúlyozni. Talán ezért is tapasztalhatjuk azt, hogy napjainkban a konferansz, a bohózat vagy a humoreszk jóval kevésbé népszerü, mint a gyors és folyamatos humorkeltésre törekvő „dumaszínház” (stand-up comedy), a szituációs komédia, a paródia, az ún. mém (I. pl. Veszelszki 2013; Istók 2018) és természetesen a hagyományos vicc.

Logikai nézőpontból úgy tekinthetünk az elme következtető képességére, mint amely premisszákból konklúziókat tud levonni, így juttatva - immár kognitív nézőpontból - az embert új belátásokhoz, kiegészítvén az információs hézagokat, $\mathrm{s}$ hozzájárulva végső soron a világról való feltevéseinek gyarapodásához, pontosításához. Sperber és Wilson (1995 [1986]) kifogásolja, hogy a társalgási implikatúrák levezetésének szabályai Grice-nál nem explicitek; homályban marad, miképpen történik a premisszák kiválasztása, honnan származnak ezek a premisszák, s mi teszi lehetővé, hogy egy adott ponton leállhasson a következtetési folyamat, és megállapítsuk, hogy eljutottunk a megnyilatkozás korrekt interpretációjához (Reboul-Moeschler 2000 [1998]: 73, 95).

A relevanciaelmélet szerint a következtetési műveletsorban a dedukció központi szerepet játszik: az ember a deduktív logika törvényeit könnyebben alkalmazza, mivel lényegileg ezen alapul intellektusunk. A deduktív okoskodás biztosítja, hogy

\footnotetext{
15 „The effort required is an effort of attention, memory and reasoning. The effect achieved is to modify the individual's cognitive environment by adding new beliefs, cancelling old ones, or merely altering the saliency or strength of existing beliefs" (Wilson-Sperber 2012: 88; eredetileg majdnem szó szerint itt: Sperber-Wilson 1990: 144).
} 
igaz premisszák esetén igaz konklúziót kapjunk. Sperber és Wilson tehát kevésbé számol azzal, hogy maga a következtetési séma is lehet nem igazságmegőrző, s emiatt esetleg igaz premisszákból is előállhat hamis konklúzió (vö. Clark 2013: 131-133). Nyilvánvaló ugyanakkor, hogy a társalgási implikatúrák félreértésekre adhatnak okot (nem demonstratív következtetések, I. a törölhetőség tulajdonságát): kikövetkeztethetünk egészen mást valakinek a megnyilatkozásából, mint amit közölni szándékolt. llyesmi a deduktív szillogizmusoknál (modus ponens, modus tollens stb.) nem történhet meg, ezért a relevanciaelmélet leginkább azzal tudja magyarázni az implikatúra félreértését, hogy a hallgató nem ugyanazokat a premisszákat vette figyelembe, mint amelyekre a beszélő alapozott (I. a kontextus felépítéséről korábban mondottakat).

A dedukció alapsémái a modus ponens és a modus tollens:

a. Dedukció (modus ponens)

$$
\begin{aligned}
& \forall(\mathrm{x})(\mathrm{P}(\mathrm{x}) \rightarrow \mathrm{Q}(\mathrm{x})) \\
& \mathrm{P}(\mathrm{a}) \\
& \mathrm{Q}(\mathrm{a}) \\
& \mathrm{D}(\mathrm{mp})
\end{aligned}
$$

Az alábbi - és minden hasonló sztereotípián alapuló - viccben a modus ponens ismerhető fel (tekintsünk el attól, hogy a hétköznapi premisszák gyakran inkább vélelmezések és általánosítások, mint tényszerüen igaz állítások):

(LVk. 313.)

A rendőr előállít két részeg skótot.

- És hol van a harmadik? - kérdezi az ügyeletes tiszt.

- Miféle harmadik?

- Hát, aki ezeknek az italt fizette.

A „Ha [...], akkor [...]” szerkezetű kondicionális előtagjában a skót $[\mathrm{P}(\mathrm{x})]$, utótagjában a rendkívül zsugori/fukar/fösvény $[Q(x)]$ szerepel. Az ügyeletes tiszt - tudván, hogy az elóálítottak skótok - a modus ponenst alkalmazva feltételezi, hogy lennie kell egy "harmadik” személynek is, aki nem skót, és a két részeg italszámláját kifizette.

A modus tollens is alapja lehet egy viccnek:

(JjV. 95.)

- Én azt hiszem, hogy ez az X nem is igazi báró!

- Miből gondolod?

- Mindig van pénze...

Ezúttal a kondicionális az lesz, hogy ha valaki „igazi báró” $[P(x)]$, akkor nincs (vagy gyakran nincs) pénze $[\mathrm{Q}(\mathrm{x})]$. S mivel X-nek mindig van pénze $[\neg \mathrm{Q}(\mathrm{a})]$, nem igazi báró $[\neg P(a)]$, legalábbis a viccbeli beszélő deduktív következtetése szerint.

A deduktív érvelés monoton tulajdonságú. A monotonitás a logikában azt jelenti, hogy ha a premisszák halmazához új elemet adunk, az nem érvényteleníti az eredeti premisszahalmazból következő konklúzió(ka)t. Mivel a társalgási implikatúrák törölhetők, Levinson (2000: 42) szerint eléggé valószínűtlen, hogy deduktív következtetéssel (monoton logikával) fejtenénk meg őket, mint ahogy azt a 
relevanciaelmélet sugallja. Inkább az a valószínű, hogy a dedukció nem játszik kitüntetett szerepet az emberi gondolkodásban. Érdemes ezért - mondja Levinson - megvizsgálni a nem monoton szillogizmusok jellemzőit, mennyire alkalmasak az implikatúrák levezetése mögött húzódó gondolkodási folyamat modellezésére. A legismertebb nem monoton szillogizmus az indukció:

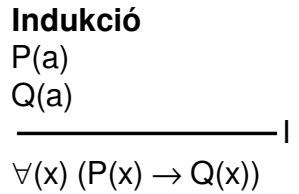

Az indukcióval általános törvényszerüségeket próbálunk felállítani egyedi tények megfigyeléséből. Ám egyetlen ellentmondó tény kihúzza a talajt a szabály alól, bármennyire is sok korábbi megfigyelés valószínűsítette meglétét. Amíg csak szőke hajú svédekkel találkozom, addig hihetem azt, hogy minden svéd szőke. Ha azután mégis szembejön velem egy barna, kiderül, hogy korábbi következtetésemet árnyalni kell.

Számos viccben tetten érhető az induktív következtetés. Nézzünk egy ilyet:

(LVk. 40.)

Nyuszika új autót kap. Rodeózik vele az erdőben. Látja, hogy integetnek, megáll, letekeri az ablakot.

- Mi vagyunk a piros mocskok, és szeretnénk kipróbálni az autódat.

- Gyertek csak, üljetek be!

Megállnak, elbúcsúznak. Nyuszika megy tovább. Látja, hogy megint integetnek.

- Mi vagyunk a sárga mocskok, és szeretnénk kipróbálni az autódat.

- Gyertek, haverok!

Mennek egy darabig, majd elbúcsúznak. Nyuszika megy tovább, megint integetnek. Megáll.

- Tudom, tudom, ti vagytok a kék mocskok, és szeretnétek kipróbálni az autómat.

- Igen? Kék mocskok?! Forgalmit, jogosítványt kérünk!

„Nyuszika” a (19)-ben vesztére alkalmazza az induktív logikát: két eset után a harmadikra már nem lesz érvényes az az általánosítás, hogy ha valakik integetnek az út mentén $[P(x)]$, akkor azok olyan színű „mocskok”, amilyen színű a külsejük/ruhájuk, és szeretnék kipróbálni az autóját $[Q(x)]$. A kék külső, valamint a forgalmi engedély és a jogosítvány bemutatására felszólító illokúciós aktus felidézi a rendőr(ség) fogalmát és a közúti igazoltatás forgatókönyvét (enciklopédikus tudás).

A harmadik „dukció”, az (indukcióhoz hasonlóan szintén nem monoton) abdukció fogalmát a szemiotikus Charles Sanders Peirce (1839-1914) vitte be a tudományos köztudatba, visszavezetve azt Arisztotelész apagógé ${ }^{16}$ fogalmára, amelyet a XV. század körül fordítottak le abdukciónak (Bencze 2008: 33). Ma az abduktív

${ }^{16} \mathrm{Az}$ Első analitika magyar kiadásában: „tétel-visszavezetés” (Arisztotelész 1979: II.25, 69a20). 
következtetéseknek egyre nagyobb jelentőséget tulajdonítanak úgy a szemiotikában (I. Sebeok-Umiker-Sebeok 1990 [1980]; Balázs-H. Varga 2008), mint az érveléselméletben (Walton 2004). Formális definíciója abban különbözik a modus ponensétől, hogy egy általános törvényszerüség alapján visszafelé következtet egy tény valószínű okára. Abból például, hogy kinézve az ablakon azt látjuk, vizes az utca, rögtön feltételezzük, hogy esett az eső (Bunt-Black 2000: 9-10). Pedig nincs kizárva, hogy a közterület-fenntartók locsolták az utakat; azonban ez kevésbé természetes és valószínü, mint az eső.

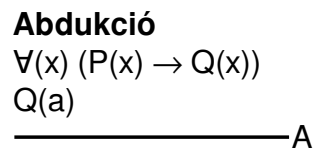

$\mathrm{P}(\mathrm{a})$

Másutt (Nemesi 2016: 159) már idéztem abdukción alapuló viccet. Nézzünk most egy humoros anekdotát, amely ugyancsak a (20) szillogizmusára támaszkodva értelmezhető:

\section{(LVk. 62.)}

Burt Lancastertől megkérdezte egy riporter, mi a titka hallatlan munkabírásának. A filmsztár így válaszolt:

- Tudja, ebéd után mindig kipihenem magam.

- Alszik?

- Én nem. A feleségem!

Mivel az emberek leginkább akkor tudják kipihenni magukat, ha eleget alszanak, teljesen természetes a riporter következtetése az alvásra mint a legvalószínúbb magyarázó okra. A híres amerikai színész - amennyiben igaz a történet, és a humor szándékos - ezt előre kiszámíthatta, felépítve rá a humoros implikatúrát (amelynek implikátuma, hogy akkor tudja magát kipihenni, amikor a felesége alszik, vagy megfordítva: ha a felesége nem alszik, nem tud vagy nem lehet mellette pihenni).

Az indukcióval és az abdukcióval nem merítettük ki a nem deduktív szillogizmusok fajtáit. Levinsonra (2000: 43-45) hivatkozva számolhatunk a „praktikus okoskodás” (practical reasoning; vö. Kenny 1966) és a „default logika” (vö. Ginsberg 1987) következtetési sémájával is:

$$
\begin{aligned}
& \text { a. „Praktikus okoskodás” } \\
& \forall(x)(P(x) \rightarrow Q(x)) \\
& \text { Cél }(\mathrm{Q}(\mathrm{a})) \\
& \hline \text { Cél }(\mathrm{P}(\mathrm{a}))
\end{aligned}
$$

b. „Default logika” $\forall(x)([P(x) \& M(Q(x))] \rightarrow Q(x))$ $\mathrm{P}(\mathrm{a})$

$$
\mathrm{Q}(\mathrm{a})
$$

A „praktikus okoskodás” a célok és a célok elérésére szolgáló eszközök, tervek közötti összefüggést igyekszik megragadni. Ha valaki, mondjuk, 2017 nyarán a 8:29-es Tokaj intercityvel megy Miskolcról Budapestre, akkor 10:30-ra a menetrend szerint odaér. Így joggal gondolhatjuk, hogy egy miskolci ismerősünk, akinek 10:40-re a Keleti pályaudvaron kell lennie, el akarja érni a 8:29-es vonatot. De mi történik akkor, ha megtudjuk, hogy egy ideje nem szeret vonaton utazni (még 
intercityvel sem), és nemrég vett magának új autót, vagy szereti ugyan a vonatközlekedést, de ezúttal különösen fontos, hogy ne késsen el, a miskolci vonalon pedig nem mindig járnak pontosan a vonatok? Ezek az információk megelőzhetik vagy érvényteleníthetik azt a „praktikus okoskodás” szerinti következtetést, hogy ha ismerősünknek az a célja, hogy időben odaérjen (és persze ne kelljen sokat várakoznia), akkor a 8:29-es vonatot fogja választani. A „praktikus okoskodás” az abdukcióhoz hasonlóan a viccek értelmezésében is kimutatható. Ezúttal a megfejtés:

(TS. 12.)

... bérrabszolgának, inkább a maga nyugdíjából élek!

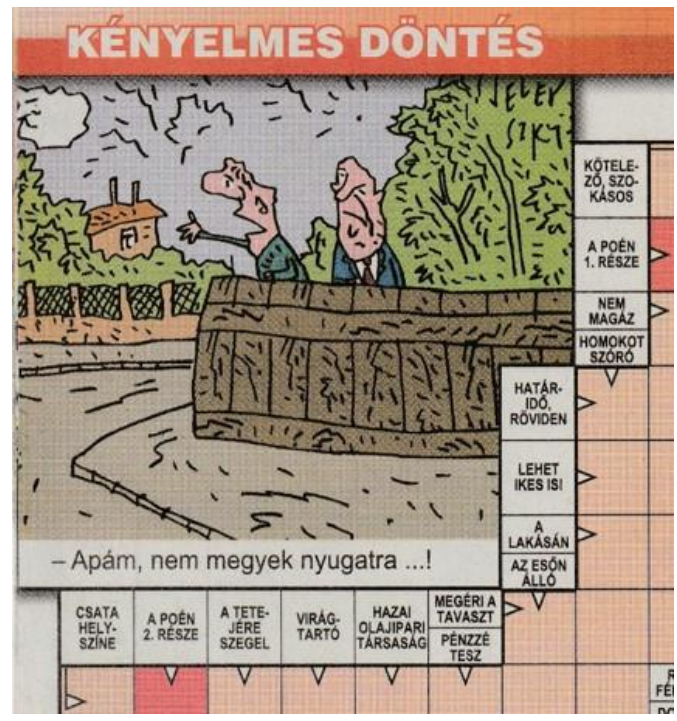

Csak úgy érthetjük meg a (23) humorát, ha abból az elterjedt nézetből indulunk ki, hogy aki biztosítani akarja a megélhetését (mondjuk, a rendszerváltozás utáni évtizedekben Magyarországon), az elmegy „nyugatra” (Nyugat-Európába) dolgozni, mert aki elmegy nyugatra $[\mathrm{P}(\mathrm{a})]$, az meg tud élni $[\mathrm{Q}(\mathrm{a})]$ az ottani keresetéböl. Ezt a „praktikus okoskodást” azonban a viccbeli fiú nem teszi magáévá: neki nem célja a $\mathrm{P}(\mathrm{a})$, hanem inkább marad, hogy az apja nyugdíjából éljen. „Kényelmes döntése” Leech (1983) tapintat- és nagylelküség-maximáinak nyilvánvaló megsértése. A nyakkendős apa ehhez való viszonyulása jól kivehető az arckifejezéséből. Hozzájárul még a humorhoz az öntudatoskodó indoklás („nem megyek [...] bérrabszolgának"), és hogy föl sem merül egyéb (hazai) munkalehetőség.

Ami pedig a „default logikát” illeti, ez azokat a következtetéseket formalizálja, amelyeket észszerü vélelmezésnek lehetne nevezni nem tipikus körülmények híján. Az M operátor jelentése a (22b)-ben: 'Q(x) konzisztens azzal, ami tudott dolog'. Például, ha azt halljuk, hogy $A$ fegyver zaja elijesztette a madarakat, rögtön arra gondolunk, hogy 'a madarak elrepültek', hacsak nincs ezzel inkonzisztens előzetes ismeretünk (pl., hogy struccokról vagy a Balatonban úszó hattyúkról van szó). 
A következtetés tehát itt is megtámadható, ha bármilyen nem tipikus körülmény merül föl - ahogy a (24)-beli viccben, amelyben a postás a tábla szövegét azzal a tudott dologgal kapcsolja össze, hogy a házőrző kutyák harapnak $[Q(x)]$, következésképp lennie kell a háznál egy harapós kutyának [Q(a)]. Kiderül azonban, hogy a figyelmeztető felirat rendhagyó módon nem a látogatókat óvja, hanem a háziak törpe rattlerét - azaz, a beszédaktus-elmélet nyelvén, az illokúciós aktus propozíciós tartalma különbözik attól, amely az ilyen tábláknál konvencionálisnak számít (vö. Nemesi 2016: 152-156):

(LVk. 47.)

Új postást kap az utca. Félve csönget be az egyik családi ház kertkapuján, mert a kerítésen hatalmas tábla hirdeti: „Vigyázat, kutya!” A csöngetésre kijön egy idős hölgy, az ölében egy törpe rattlerrel.

- Van másik kutyája is?

- Nincsen.

- Akkor miért ijesztgeti az embereket ezzel a hatalmas táblával?

Mire a hölgy:

- Hogy rá ne lépjenek...

A legtöbb vicc és más humoros szöveg számos premisszát bevonó, összetett, többlépcsős következtetést igényel, nem vezethető vissza egyetlen klasszikus szillogizmusra. S bár nincsenek statisztikailag érvényes adataink arról, milyen arányt képviselnek a deduktív, és milyet a nem monoton következtetési sémák valamilyen reprezentatív humorkorpuszban, egy olyan megállapítás, hogy a „vicclogika” (vagy tágabban: a humorlogika) deduktív természetű lenne, a föntiek alapján is cáfolható. Mindenesetre külön kell választanunk a humoros történetek belső logikáját, az egyes szereplők logikáját, valamint a befogadótól a mentális feldolgozás során elvárt formális és informális logikai következtetési műveleteket - okkal feltételezve, hogy az ideális (a humort megértő) befogadó következtetési lépései szükségképpen integrálják az előbbieket. A vicclogikát több szerző (pl. Ziv 1984; AttardoRaskin 1991) a „konvencionális” logikától eltérőnek tekinti, azonban bizonyítani ez ideig senkinek sem sikerült, hogy a humort eredményező helytelen következtetések mögött valóban más érvelési rendszer állna (Ritchie 2014). Ellenkezőleg: épp a konvencionális logika (megsértése) adja az effajta humor magyarázatát.

\section{6. Összegzés}

A relevanciaelmélet a pragmatikakutatók körében rendkívül népszerü, gyorsan fejlődő, mára a humorkutatásban is számon tartott irányzat (I. Goatly 2012: 247-275; Yus 2017). Javára írtuk dinamikus kontextusfelfogását és az információfeldolgozási folyamat számos, korábban elhanyagolt vagy felületesen tárgyalt elemének kifejtését (az explikatúrák és implikatúrák levezetése, a félreértések magyarázata, a metareprezentációs képesség). Miként a klasszikus pragmatikaelméletekre, úgy a relevanciaelméletre is érvényes, hogy a humorjelenségekkel való szembesítés olyan kihívást jelent, amely jól kitapinthatóvá teszi a lehető legáltalánosabban megfogalmazott elmélet erősségeit és gyengéit. A humor - bár nem minden formája fér bele az osztenzív-következtetéses kommunikáció fogalmába - különben sem 
kerülhető meg, ha nem kevesebb a célunk, mint hogy megértsük, hogyan értjük meg (és persze félre) egymást. Tudjuk, hogy viszonylagos, szituáció- és kultúrafüggő, nemritkán agresszív vagy énleértékelő tónusú, de pszichés, társas-társadalmi és intellektuális haszna rendszerint kárpótol azért a kisebb-nagyobb szellemi többletmunkáért, amelyet inkongruens karaktere megkövetel.

Relevanciaelméleti keretben gondolkodva az inkongruencia kezelése azért okoz fejtörést, mert ha a megértés során át kell váltani a kommunikatív relevancia elve által vezérelt maximálisan releváns értelmezésről egy másikra, akkor a humoros szöveg által kínált első értelmezés igazából mégsem bizonyul maximálisan relevánsnak, vagyis a szöveg megsérti az egyébként megsérthetetlennek feltételezett relevanciaelvet (Attardo 2017: 182). Sperber és Wilson (1995 [1986]: 162) ugyanis kiemeli, hogy - a grice-i (1975) együttműködési alapelvvel ellentétben - az osztenzív-következtetéses kommunikációt irányító kommunikatív relevanciaelvet a kommunikátorok nem tudják sem „követni”, sem „megsérteni”, hiába is akarnák, mert az kivétel nélküli, erre van az elménk „felkészülve”. Láttuk, hogy a humoros megnyilatkozásoknál is automatikusan müködésbe lép, de nem hoz elégséges végeredményt, legalábbis az első értelmezési körben. Ezért merül fel, hogy humoros céllal tudatosan ki lehet azért használni (Yus 2016), és egy második interpretációs szinten mindenképp relevánsnak kellene tekinteni a humoros stimulust (Clark 2013). Tisztázatlan azonban, mi a humoros hatás tulajdonképpeni státusa a relevanciaelméletben - nyilvánvaló „nyereség”, amely ellensúlyozni képes a megértési „befektetést”, de vajon „kognitív” nyereség-e? Mert, ha igen, akkor a kogníció fogalmát pontosítani szükséges, ha viszont nem, akkor kívül esik az elmélet hatókörén, és végső soron a relevanciaelmélet (mint kommunikációelmélet) részlegességére világít rá.

A grice-i modellel való összevetésből a poszt-grice-i szakirodalomban Wilson és Sperber (1981) cikke óta rendre a relevanciaelmélet erényei domborodnak ki, de jegyezzük meg, hogy a relevanciaelmélet, mivel mellőzi a társalgási elvárások (maximák) figyelembevételét, nem rendelkezik olyan predikciós erővel, mint amit a grice-i (és leechi) maximák jelentenek (különösen a „Kerüld a kétértelműséget!” módmaxima). Jóslata csupán annyi, hogy ha egy osztenzív (vagy annak látszó) stimulus automatikus, relevanciaelv szerinti interpretációja nem bizonyul kielégítőnek, akkor fennáll az esélye annak, hogy humoros szándékkal hozták létre, és egy újraértelmezési folyamat ezt igazolhatja vagy cáfolhatja. Természetesen a grice-i és leechi maximák sérelme sem elégséges feltétele a humornak, ám többet tudnak hozzáadni a humor magyarázatához, mint a kommunikatív relevancia elve. $A z$ irónia esetét véve: kiderült, hogy a relevanciaelmélet iróniafelfogása egyrészt nem öleli fel az irónia összes példáját, másrészt nem magyarázza meg, miért érezzük oly gyakran humorosnak az iróniát. A társalgási maximák elmélete azt mondaná, azért, mert az irónia megsért valamilyen - tipikusan az udvariasság alapelvének alárendelt - maximát, és ez a többé-kevésbé implicit normasértés (inkongruencia) egy adott kultúrában és azon belül egy adott szituációban humoros. A humorpercepció kulturális különbségeire a maximák kultúraspecifikus definiálása és rangsorolása lehet a válasz, míg a relevanciaelmélet legfeljebb az enciklopédikus feltevések eltéréseit hangsúlyozhatja.

Mindebből kitűnik, hogy a humor relevanciaelméleti interpretációja mélyen érinti az elmélet alaptéziseit, és amíg ezek nagyjából változatlanok, addig a fönti 
kérdésfelvetésekre nem könnyű igazán meggyőző válaszokat adni. Yus (2016) monográfiája mindenesetre olyan friss, színvonalas, ötletekben, rendszerezésekben és részelméletekben bővelkedő összefoglalása a humor eddigi relevanciaelméleti vizsgálatának, amely ezután megkerülhetetlen lesz a humorkutatásban, és sok tekintetben hozzájárulhat az egész elmélet további fejlődéséhez.

\section{Források}

JjV. = Kisbán Gyula - Meggyesi Éva (szerk.) 1988. Jobbnál-jobb vicczek. Válogatás a századforduló humorából. Budapest: Magyar Hirdető.

Kellér Dezső 1957. Kedves Közönség. Válogatott konferanszok. Budapest: Szépirodalmi Könyvkiadó.

LVk. = Köves József (szerk.) 1999. A legnagyobb vicckönyv 10000 viccel. Budapest: K.u.K. Kiadó.

MA. = Peter Hay 1990. Movie Anecdotes. Oxford: Oxford University Press. Nádassy László: A tacskó. Bohózat. https://www.youtube.com/watch?v=j93LRQ7CQCs (2018. 08. 15.)

Petőfi Sándor 1844. A helység kalapácsa. Hősköltemény négy énekben. Budapest.

TS. = Trend Skandi rejtvénylap 2015/16. Székesfehérvár, CsoSch Bt.

ZA. = Márkus József (szerk.) 2011. Zenei anekdoták, aforizmák és viccek. Budapest: Rózsavölgyi.

\section{Hivatkozások}

Arisztotelész 1979. Organon. Fordította Szalai Sándor. (Filozófiai írók tára (új folyam) 35) Budapest: Akadémiai Kiadó.

Árvay Anett 2003. A manipuláció és a meggyőzés pragmatikája a magyar reklámszövegekben. In Németh T. Enikő - Bibok Károly (szerk.) Általános Nyelvészeti Tanulmányok XX. Tanulmányok a pragmatika köréból. Budapest: Akadémiai Kiadó. 11-35.

Árvay, Anett 2004. Pragmatic aspects of persuasion and manipulation in written advertisements. Acta Linguistica Hungarica 51/3-4:231-263. doi:10.1556/ALing.51.2004.3-4.2.

Attardo, Salvatore 1994. Linguistic Theories of Humor. Berlin: Walter de Gruyter.

Attardo, Salvatore 2017. Humor and pragmatics. In Salvatore Attardo (szerk.) The Routledge Handbook of Language and Humor. (Routledge Handbooks in Linguistics) New York: Routledge. 174-188.

Attardo, Salvatore - Jodi Eisterhold - Jennifer Hay - Isabella Poggi 2003. Multimodal markers of irony and sarcasm. Humor: International Journal of Humor Research 16/2:243-260. doi:10.1515/humr.2003.012.

Attardo, Salvatore - Lucy Pickering - Amanda Baker 2011. Prosodic and multimodal markers of humor in conversation. Pragmatics \& Cognition 19/2:224-247. doi:10.1075/pc.19.2.03att.

Attardo, Salvatore - Victor Raskin 1991. Script theory revis(it)ed: Joke similarity and joke representation model. Humor: International Journal of Humor Research 4/3-4:293-347. doi:10.1515/humr.1991.4.3-4.293. 
Austin, John Langshaw 1990 [1962]. Tetten ért szavak. Fordította Pléh Csaba. Budapest: Akadémiai Kiadó.

Bach, Kent 1994. Conversational impliciture. Mind \& Language 9/2:124-162. doi:10.1111/j.1468-0017.1994.tb00220.x.

Balázs Géza - H. Varga Gyula (szerk.) 2008. Az abdukció. Budapest, Eger: Magyar Szemiotikai Társaság, Líceum Kiadó.

Bárány Tibor - Zvolenszky Zsófia - Tőzsér János (szerk.) 2015. Metafora, relevancia, jelentés. (Pragmatika 3) Budapest: Loisir Kiadó.

Bencze Lóránt 2008. Az abdukcióról - antropológiai nyelvészeti szempontból. In Balázs Géza - H. Varga Gyula (szerk.) Az abdukció. Budapest, Eger: Magyar Szemiotikai Társaság, Líceum Kiadó. 28-37.

Biegajło, Magdalena 2013. Relevance at the centre of humorous communication: On finding the conceptual tools which carry explanatory power in the model of the comprehension of jokes. Acta Philologica 44:31-41.

Blakemore, Diane 1992. Understanding Utterances. (Blackwell Textbooks in Linguistics 6) Oxford, Cambridge: Blackwell.

Brock, Alexander 2011. Bumcivilian. Systemic aspects of humorous communication in comedies. In Roberta Piazza - Monika Bednarek - Fabio Rossi (szerk.) Telecinematic Discourse. Approaches to the Language of Films and Television Series. (Pragmatics \& Beyond New Series 211) Amsterdam: John Benjamins Publishing Company. 263-280. doi:10.1075/pbns.211.17bro.

Bunt, Harry - William Black (szerk.) 2000. Abduction, Belief and Context in Dialogue. Studies in Computational Pragmatics. (Natural Language Processing 1) Amsterdam: John Benjamins Publishing Company.

Carston, Robyn 2002. Thoughts and Utterances. The Pragmatics of Explicit Communication. Oxford: Wiley-Blackwell.

Clark, Herbert H. 1996. Using Language. Cambridge, New York: Cambridge University Press.

Clark, Billy 2013. Relevance Theory. Cambridge: Cambridge University Press.

Clark, Herbert H. - Richard J. Gerrig 1984. On the pretense theory of irony. Journal of Experimental Psychology: General 113/1:121-126. doi:10.1037/00963445.113.1.121.

Curcó, Carmen 1995. Some observations on the pragmatics of humorous interpretations: A relevance theoretic approach. UCL Working Papers in Linguistics 7:27-47.

Curcó, Carmen 1996. The implicit expression of attitudes, mutual manifestness, and verbal humour. UCL Working Papers in Linguistics 8:89-99.

Csabai Márta - Erős Ferenc 2000. Testhatárok és énhatárok. Az identitás változó keretei. Budapest: Jószöveg Mühely.

Dynel, Marta 2009. Humorous Garden-Paths: A Pragmatic-Cognitive Study. Newcastle upon Tyne: Cambridge Scholars Publishing.

Dynel, Marta 2011. "You talking to me?" The viewer as a ratified listener to film discourse. Journal of Pragmatics 43/6:1628-1644. doi:10.1016/j.pragma.2010.11.016.

Dynel, Marta 2013. Irony from a neo-Gricean perspective: On untruthfulness and evaluative implicature. Intercultural Pragmatics 10/3:403-431. doi:10.1515/ip-2013-0018. 
Dynel, Marta 2018. Deconstructing the myth of positively evaluative irony. In Manuel Jobert - Sandrine Sorlin (szerk.) The Pragmatics of Irony and Banter. (Linguistic Approaches to Literature 30) Amsterdam: John Benjamins Publishing Company. 41-57. doi:10.1075/lal.30.03dyn.

Fónagy Iván 1970. Viccel a bácsi. Humor és költőiség a nyelvben. Magyar Nyelvôr 94/1:16-43.

Franken, Nathalie 1999. The status of the principle of relevance in relevance theory. In Jef Verschueren (szerk.) Pragmatics in 1998. Selected Papers from the 6th International Pragmatics Conference. Vol. 2 Antwerpen: IPrA. 142-158.

Garmendia, Joana 2010. Irony is critical. Pragmatics \& Cognition 18/2:397-421. doi:10.1075/pc.18.2.07gar.

Garmendia, Joana 2014. The Clash: Humor and critical attitude in verbal irony. Humor: International Journal of Humor Research 27/4:641-659. doi:10.1515/humor-2014-0094.

Garmendia, Joana 2015. A (neo)Gricean account of irony: An answer to relevance theory. International Review of Pragmatics 7/1:40-79. doi:10.1163/18773109-00701003.

Gibbs, Raymond W. Jr. - Herbert L. Colston 2012. Interpreting Figurative Meaning. Cambridge: Cambridge University Press.

Gil, José María 2011. Relevance theory and unintended transmission of information. Intercultural Pragmatics 8/1:1-40. doi:10.1515/IPRG.2011.001.

Ginsberg, Matthew L. (szerk.) 1987. Readings in Nonmonotonic Reasoning. Los Altos: Morgan Kaufmann Publishers.

Goatly, Andrew 2012. Meaning and Humour. Cambridge: Cambridge University Press.

Grice, H. Paul 1975. Logic and conversation. In Peter Cole - Jerry L. Morgan (szerk.) Syntax and Semantics Vol. 3. Speech Acts. New York: Academic Press. 41-58.

Grice, H. Paul 1978. Further notes on logic and conversation. In Peter Cole (szerk.) Syntax and Semantics, Vol. 9. Pragmatics. New York: Academic Press. 113128.

Grice, H. Paul 2011 [1989]. Tanulmányok a szavak életéról. Budapest: Gondolat Kiadó.

Istók Béla 2018. Humoros vagy sértő? Az internetes mémek elmélete és gyakorlata. Századvég 87:127-153.

Ivaskó Lívia 2005. Félreértéseink nyomában. In Ivaskó Lívia (szerk.) Érthető kommunikáció. Szeged: SZTE Médiatudományi Tanszék. 14-26.

Ivaskó, Lívia - Enikő Németh T. 2002. Types and reasons of communicative failures: A relevance theoretical approach. Modern Filológiai Közlemények 4/1:31-43.

Jodłowiec, Maria 1991. What makes jokes tick. UCL Working Papers in Linguistics 3:241-253.

Kenny, Anthony J. P. 1966. Practical inference. Analysis 26:65-75.

Keszler Borbála (szerk.) 2000. Magyar grammatika. Budapest: Nemzeti Tankönyvkiadó.

Komlósi Boglárka 2007. Az iróniakutatás elméleti dilemmái. Nyelvtudomány 34:95-128. 
Komlósi Boglárka 2014. Most ironizálsz? Az irónia és az irónia kulcsingerei a különböző nyelvi szinteken. Magyar Nyelvör 138/2:226-244.

Kövecses Zoltán 2005 [2002]. A metafora. Gyakorlati bevezetés a kognitív metaforaelméletbe. Budapest: Typotex Kiadó.

Kumon-Nakamura, Sachi - Sam Glucksberg - Mary Brown 1995. How about another piece of pie: The allusional pretense theory of discourse irony. Journal of Experimental Psychology: General 124:3-21.

Lakoff, George - Mark Turner 1989. More Than Cool Reason: A Field Guide to Poetic Metaphor. Chicago: The University of Chicago Press.

Leech, Geoffrey N. 1983. Principles of Pragmatics. London: Longman.

Leezenberg, Michiel 2001 [1995]. Contexts of Metaphor. (Current Research in the Semantics/Pragmatics Interface 7) Amsterdam: Elsevier.

Levinson, Stephen C. 1989. A review of Relevance. Journal of Linguistics 25/2:455-472.

Levinson, Stephen C. 2000. Presumptive Meanings: The Theory of Generalized Conversational Implicature. Cambridge: The MIT Press.

Martin, Rod A. 2007. The Psychology of Humor. An Integrative Approach. Amsterdam: Elsevier.

Nemesi Attila László 2009. Az alakzatok kérdése a pragmatikában. Budapest: Loisir Könyvkiadó.

Nemesi Attila László 2012. Gyenge implikatúrák. In Szikszainé Nagy Irma (szerk.) A stilisztikai-retorikai alakzatok szöveg- és stílusstruktúrát meghatározó szerepe. Debrecen: Debreceni Egyetemi Kiadó. 81-96.

Nemesi, Attila László 2015a. Levels and types of breaking the maxims: A neoGricean account of humor. Intercultural Pragmatics 12/2:249-276. doi:10.1515/ip-2015-0012.

Nemesi Attila László 2015b. Melyik pragmatikaelméletnek van a legjobb „humorérzéke”? In Bódog Alexa - Csatár Péter - Németh T. Enikő (szerk.) Használat és hatás. Újabb eredmények a magyarországi pragmatikai kutatásokban. Budapest: Loisir Könyvkiadó. 123-156.

Nemesi Attila László 2016 [2011]. Nyelv, nyelvhasználat, kommunikáció. Budapest: Loisir Kiadó.

Nemesi Attila László 2016. Beszédaktusviccek. In Boda-Ujlaky Judit - Barta Zsuzsanna - T. Litovkina Anna - Barta Péter (szerk.) A humor nagyítón keresztül. (Segédkönyvek a nyelvészet tanulmányozásához 188) Budapest: Tinta Könyvkiadó. 148-162.

Nemesi Attila László 2018. Nyelvészeti humorelméletek. Századvég 87:41-55.

Németh T. Enikő 2003. A kommunikatív nyelvhasználat elvei. In Németh T. Enikő Bibok Károly (szerk.) Általános Nyelvészeti Tanulmányok XX. Tanulmányok a pragmatika köréból. Budapest: Akadémiai Kiadó. 221-254.

Németh T. Enikő 2006. Pragmatika. In Kiefer Ferenc (szerk.) Magyar nyelv. Budapest: Akadémiai Kiadó. 222-261.

Németh T. Enikő 2011. A humán kommunikáció modelljei és az ember-gép kommunikáció. In Németh T. Enikő (szerk.) Ember-gép kapcsolat: a multimodális ember-gép kommunikáció modellezésének alapjai. (Segédkönyvek a nyelvészet tanulmányozásához 133) Budapest: Tinta Könyvkiadó. 43-61. 
Németh T. Enikő 2013a. Nyelvhasználat, nyelvtan és pragmatika. Magyar Nyelvőr 109/2:184-191.

Németh T. Enikő 2013b. Intenciók és nézőpontok a nyelvhasználatban. In Kugler Nóra - Laczkó Krisztina - Tátrai Szilárd (szerk.) A megismerés és az értelmezés konstrukciói. Tanulmányok Tolcsvai Nagy Gábor tiszteletére. Budapest: Tinta Könyvkiadó. 112-126.

Németh T., Enikő 2015. The role of perspectives in various forms of language use. Semiotica 2015/203:53-78. doi:10.1515/sem-2014-0072.

Noveck, Ira A. - Dan Sperber (szerk.) 2004. Experimental Pragmatics. (Palgrave Studies in Pragmatics, Language and Cognition 1) Basingstoke: Palgrave Macmillan.

Pilkington, Adrian 1992. Poetic effects. Lingua 87/1:29-51. doi:10.1016/00243841(92)90024-D.

Pilkington, Adrian 2000. Poetic Effects. A Relevance Theory Perspective. (Pragmatics \& Beyond New Series 75) Amsterdam: John Benjamins Publishing Company.

Piskorska, Agnieszka 2005. Can we have a recipe for humour in Relevance Theory? In Piotr Cap (szerk.) Pragmatics today. Frankfurt am Main: Peter Lang. 245-253.

Raskin, Victor 1985. Semantic Mechanisms of Humor. (Studies in Linguistics and Philosophy) Dordrecht: Reidel.

Reboul, Anne - Jacques Moeschler 2000 [1998]. A társalgás cselei. Bevezetés a pragmatikába. Fordította Gécseg Zsuzsanna. Budapest: Osiris Kiadó.

Recanati, François 2004. Literal Meaning. Cambridge: Cambridge University Press.

Ritchie, Graeme 2014. Logic and reasoning in jokes. The European Journal of Humour Research 2/1:50-60. doi:10.7592/EJHR2014.2.1 .ritchie.

Schnurr, Stephanie 2010. Humour. In Miriam A. Locher - Sage L. Graham (szerk.) Interpersonal Pragmatics. Berlin, New York: De Gruyter Mouton. 307-326.

Searle, John R. 2009 [1969]. Beszédaktusok. Fordította Bárány Tibor. Budapest: Alkalmazott Kommunikációtudományi Intézet, Gondolat.

Sebeok, Thomas A. - Jean Umiker-Sebeok 1990 [1980]. Ismeri a módszeremet? Avagy: a mesterdetektív logikája. Budapest: Gondolat.

Sperber, Dan (szerk.) 2000. Metarepresentations. A Multidisciplinary Perspective. Oxford: Oxford University Press.

Sperber, Dan - Fabrice Clément - Christophe Heintz - Olivier Mascaro - Hugo Mercier - Gloria Origgi - Deirdre Wilson 2010. Epistemic vigilance. Mind \& Language 25/4:359-393. doi:10.1111/j.1468-0017.2010.01394.x.

Sperber, Dan - Deirdre Wilson 1981. Irony and the use-mention distinction. In Peter Cole (szerk.) Radical Pragmatics. New York: Academic Press. 295-239.

Sperber, Dan - Deirdre Wilson 1990. Rhetoric and relevance. In John Bender David E. Wellbery (szerk.) The Ends of Rhetoric. History, Theory, Practice. Stanford: Stanford University Press. 140-156.

Sperber, Dan - Deirdre Wilson 1995 [1986]. Relevance. Communication and Cognition. Oxford, Cambridge: Blackwell.

Sperber Dan - Wilson Deirdre 2013 [2008]. A metafora leleplezése. In Pléh Csaba (szerk.) Általános nyelvészeti tanulmányok XXV. A kognitív szempont a nyelv pszichológiájában. Budapest: Akadémiai Kiadó. 313-338. 
Tátrai Szilárd 2004. A kontextus fogalmáról. Magyar Nyelvőr 128/4:479-494.

Tátrai Szilárd 2011. Bevezetés a pragmatikába. Funkcionális kognitív megközelítés. (Segédkönyvek a nyelvészet tanulmányozásához 131) Budapest: Tinta Könyvkiadó.

Tátrai Szilárd 2017. Pragmatika. In Tolcsvai Nagy Gábor (szerk.) Nyelvtan. (A magyar nyelv kézikönyvtára 4) Budapest: Osiris Kiadó. 897-1058.

Vega Moreno, Rosa E. 2007. Creativity and Convention. The Pragmatics of Everyday Figurative Speech. (Pragmatics \& Beyond New Series 156) Amsterdam: John Benjamins Publishing Company.

Verschueren, Jef 1999. Understanding Pragmatics. London: Arnold Publishers.

Veszelszki Ágnes 2013. Humor a digitális kommunikációban: az internetes mémek. In Vargha Katalin - T. Litovkina Anna - Barta Zsuzsanna (szerk.) Sokszínú humor. A III. Magyar Interdiszciplináris Humorkonferencia előadásai. (Segédkönyvek a nyelvészet tanulmányozásához 151) Budapest: Tinta Könyvkiadó, ELTE Bölcsészettudományi Kar, Magyar Szemiotikai Társaság. 11-25.

Walton, Douglas N. 2004. Abductive Reasoning. Tuscaloosa: University of Alabama Press.

Wilson, Deirdre 2011. Parallels and differences in the treatment of metaphor in relevance theory and cognitive linguistics. Intercultural Pragmatics 8/2:177196. doi:10.1515/iprg.2011.009.

Wilson, Deirdre - Dan Sperber 1981. On Grice's theory of conversation. In Paul Werth (szerk.) Conversation and Discourse. New York: Croom Helm. 155178.

Wilson, Deirdre - Dan Sperber 1992. On verbal irony. Lingua 87/1:53-76. doi:10.1016/0024-3841(92)90025-E.

Wilson, Deirdre - Dan Sperber 2004. Relevance Theory. In Laurence R. Horn Gregory Ward (szerk.) The Handbook of Pragmatics. Oxford: Blackwell. 607632.

Wilson, Deirdre - Dan Sperber 2012. Meaning and Relevance. Cambridge: Cambridge University Press.

Yamaguchi, Haruhiko 1988. How to pull strings with words: Deceptive violations in the garden-path joke. Journal of Pragmatics 12/3:323-337. doi:10.1016/0378-2166(88)90036-7.

Yus, Francisco 1999. Misunderstandings and explicit/implicit communication. Pragmatics 9/4:487-517. doi:10.1075/prag.9.4.01yus.

Yus, Francisco 2003. Humor and the search for relevance. Journal of Pragmatics 35/9 (The Pragmatics of Humor):1295-1331. doi:10.1016/S0378-2166(02)00179-0.

Yus, Francisco 2008. A relevance-theoretic classification of jokes. Lodz Papers in Pragmatics 4/1:131-157. doi:10.2478/v10016-008-0004-4.

Yus, Francisco 2016. Humour and Relevance. (Topics in Humor Research 4) Amsterdam, Philadelphia: John Benjamins Publishing Company.

Yus, Francisco 2017. Relevance-theoretic treatments of humor. In Salvatore Attardo (szerk.) The Routledge Handbook of Language and Humor. (Routledge Handbooks in Linguistics) New York: Routledge. 189-203.

Ziv, Avner 1984. Personality and Sense of Humor. New York: Springer. 
Zvolenszky Zsófia - Bárány Tibor 2015. Relevanciaelmélet és a szó szerintimetaforikus kontinuum - a magyar nyelvü szövegek tükrében. In Bárány Tibor - Zvolenszky Zsófia - Tőzsér János (szerk.) Metafora, relevancia, jelentés. (Pragmatika 3) Budapest: Loisir Kiadó. 11-28.

\section{A szerzőről}

Nemesi Attila László a Pázmány Péter Katolikus Egyetem Magyar Nyelvészeti Tanszékének docense. Szűkebb kutatási területe a figuratív nyelvhasználat (trópusok, gondolatalakzatok) és a humor pragmatikája, tágabban pedig a pragmatika, a retorika, a szemiotika és a szociálpszichológia határkérdéseivel (udvariasság, benyomáskeltés, nyelvi és képi befolyásolás) foglalkozik.

Elérhetősége: nemesi.attila@btk.ppke.hu 